Review

\title{
Biophysical Tools to Study Cellular Mechanotransduction
}

\author{
Ismaeel Muhamed ${ }^{1, *}$, Farhan Chowdhury ${ }^{2, *}$ and Venkat Maruthamuthu ${ }^{3, *}$ \\ 1 Joint Department of Biomedical Engineering, University of North Carolina at Chapel Hill and North \\ Carolina State University, Raleigh, NC 27695, USA \\ 2 Department of Mechanical Engineering and Energy Processes, Southern Illinois University Carbondale, \\ Carbondale, IL 62901, USA \\ 3 Department of Mechanical and Aerospace Engineering, Old Dominion University, Norfolk, VA 23529, USA \\ * Correspondence: ismaeelmuhamed@ncsu.edu (I.M.); farhan.chowdhury@siu.edu (F.C.); \\ vmarutha@odu.edu (V.M.); Tel.: +1-919-515-8002 (I.M.); +1-618-453-7833 (F.C.); +1-757-683-4978 (V.M.)
}

Academic Editor: Gou-Jen Wang

Received: 10 October 2016; Accepted: 2 February 2017; Published: 7 February 2017

\begin{abstract}
The cell membrane is the interface that volumetrically isolates cellular components from the cell's environment. Proteins embedded within and on the membrane have varied biological functions: reception of external biochemical signals, as membrane channels, amplification and regulation of chemical signals through secondary messenger molecules, controlled exocytosis, endocytosis, phagocytosis, organized recruitment and sequestration of cytosolic complex proteins, cell division processes, organization of the cytoskeleton and more. The membrane's bioelectrical role is enabled by the physiologically controlled release and accumulation of electrochemical potential modulating molecules across the membrane through specialized ion channels (e.g., $\mathrm{Na}^{+}, \mathrm{Ca}^{2+}$, $\mathrm{K}^{+}$channels). The membrane's biomechanical functions include sensing external forces and/or the rigidity of the external environment through force transmission, specific conformational changes and/or signaling through mechanoreceptors (e.g., platelet endothelial cell adhesion molecule (PECAM), vascular endothelial (VE)-cadherin, epithelial (E)-cadherin, integrin) embedded in the membrane. Certain mechanical stimulations through specific receptor complexes induce electrical and/or chemical impulses in cells and propagate across cells and tissues. These biomechanical sensory and biochemical responses have profound implications in normal physiology and disease. Here, we discuss the tools that facilitate the understanding of mechanosensitive adhesion receptors. This article is structured to provide a broad biochemical and mechanobiology background to introduce a freshman mechano-biologist to the field of mechanotransduction, with deeper study enabled by many of the references cited herein.
\end{abstract}

Keywords: mechanotransduction; traction force microscopy; magnetic twisting cytometry; shear flow microfluidic device; integrins; focal adhesions; cadherins; adherens junction

\section{Mechanotransduction}

Mechanotransduction is an umbrella term to describe any biochemical cellular response generated against specific extracellular or intracellular mechanical stimuli [1-5]. More precisely, mechanotransduction is the process that converts mechanical force into specific biochemical signals [6,7]. The process involves force reception (mechanosensitivity/force recognition), force transduction and a corresponding response [8,9]. The biomechanical activation of certain membrane, cytosolic and nuclear proteins (e.g., growth factor associated adhesion receptors, cytoskeletal filaments, kinases and phosphatases, lamins, linker of nucleoskeleton and cytoskeleton (LINC) complexes and histone modifying proteins) that sense and/or transduce force is well 
established $[4,10,11]$. A whole host of elements are involved in the consequent cellular responses including, but not limited to, membrane associated protein classes such as stretch-activated ion channels, cell-cell adhesion receptors (cadherins, ICAM), gap junctions, cell-matrix adhesion proteins (integrins, syndecans, CD44), extracellular matrix proteins (fibronectin, collagen isoforms, laminin isoforms, proteoglycans, basement membrane), cytoskeletal components (actin microfilament, microtubule and intermediate filaments), nuclear lamins and associated proteins, growth factor receptors (epidermal growth factor receptor (EGFR), vascular endothelial growth factor receptor (VEGFR), platelet derived growth factor receptor (PDGFR)), and intracellular tension regulating components (myosin motors) [5]. These elements under specific mechanosensory stimulation regulate physiological functions $[3,12]$.

\subsection{Mechanosensitivity}

Cells sense their environment using specific cell surface receptors, and some are classified as mechanosensors when they sense mechanical cues and induce appropriate biochemical events (consequently the term mechanoreceptors) $[2,12,13]$. The ability to recognize specific mechanical stimuli is mechanosensitivity [14-16] (Figure 1). Mechanosensing receptors induce a variety of biochemical signals like conformation changes within the protein [17-21], biochemical activation and/or the recruitment of certain molecules [18,20,22-24]. These mechanically induced events modulate cell functions like migration [25], cell polarity [26,27], proliferation [28], differentiation [1], apoptosis [29,30], gene expression [8,31], and enable cells to adapt to the mechanical stimulus. Defects in mechanotransduction pathways are implicated in diseases such as muscular dystrophies [29], cardiomyopathies, atherosclerosis [13] and cancer metastasis [32].

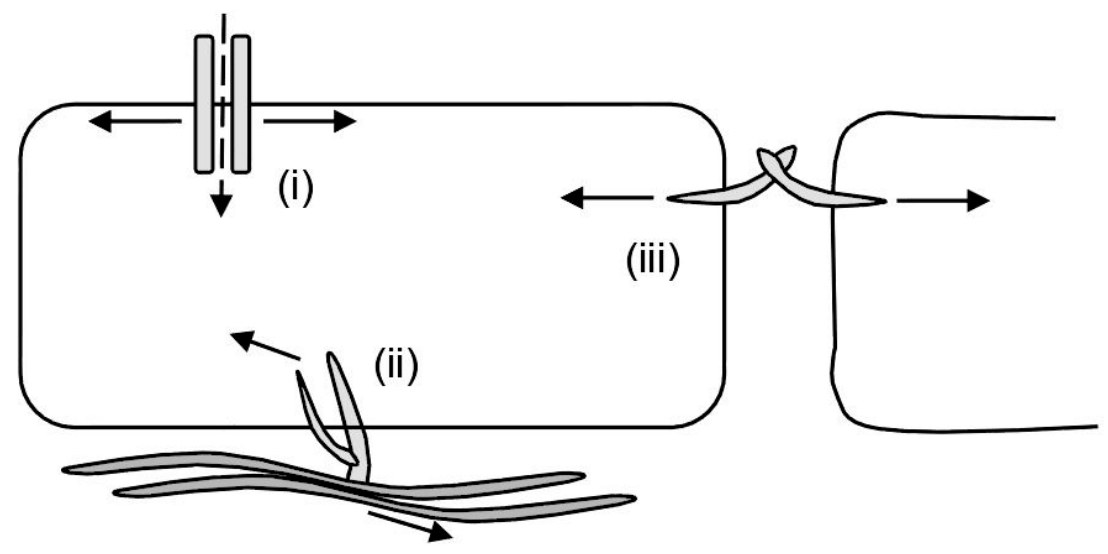

Figure 1. Three representative modes of mechanosensing by cells. Cells can use (i) mechanosensitive ion channels and receptors; (ii) mechanosensitive cell-ECM (extracellular matrix) interactions; and (iii) mechanosensitive cell-cell interactions. Solid arrows indicate forces acting on the mechanosensitive elements and the dashed arrow indicates ion conduction.

\subsection{Mechanotransduction Related Diseases}

Mechanotransduction related cell signals have a critical role in the maintenance of tissues (muscle, bone, cartilage and vessels [29]), directing stem cell fate [1,33] and cell morphogenesis [34-36]. A common feature among many mechanotransduction related diseases is the disruption in force transmission between the extracellular matrix (ECM), cytoskeleton and/or nucleoskeleton [29], which either delay or affect the signal threshold in producing the necessary conformation change or activation of the mechanosensory complex.

An example of a well-known mechanotransduction phenomenon is how inner ear hair cells transduce mechanical vibratory force into neural signals. The human ear has 3 major parts—outer, middle and inner ear. The outer ear receives and directs sound waves to the middle ear through 
the eardrum, the middle ear has many tiny bones that connect sound waves to the inner ear and the inner ear houses the cochlea, which is lined by inner ear hair cells in the organ of Corti $[37,38]$. These cells have fine hair like bundle protrusions called stereocilia that are arranged hexagonally [37,39]. The stereocilia are aligned in the order of their heights and are connected at their tips through tip link proteins. Mechanical vibratory forces cause displacements (tip elongation) in the serially height-wise organized tips of hair cells [39]. The sound waves deflect the arranged hair cells and produce tension in the connected tip links between the organized sterocilia [38]. This tension opens up mechanically gated ion channels and/or extend the elastic ankyrin protein repeats [39]. Any defect in tip link extension or mutations in cadherin 23 functional modules cause a loss in hearing [39].

Other examples of mechanically sensitive ion channels include TWIK related $\mathrm{K}^{+}$channel (TREK), TWIK-related arachidonic acid stimulated $\mathrm{K}^{+}$channel (TRAAK) and piezo (Fam38A and Fam38B) channels. TREK and TRAAK are mechanosensitive $\mathrm{K}^{+}$channels which are mechanically activated form the lipid membrane in the absence of other cytosolic components [40,41]. Piezo channels are expressed in many organs including kidney, bladder, and lung, and on stretching rapidly allow ion passage [42]. The piezo protein homo-associates, forming a pore that is selective for cation transport [43,44], and in vitro purified piezo proteins embedded within lipid bilayers are mechanically sensitive to membrane perturbation, suggesting independence from other proteins in inducing mechanosensitivity [45]. Piezo co-immunoprecipitates with polycystin (a member of the transient receptor potential (TRP) family), stomatin-like protein 3 (STOML3) and trefoil factor family1 (TFF1) in different cell lines [46]. Polycystin inhibits [47], while interaction with STOML3 amplifies piezo mechanosensitivity [48]. The mechanical stretching and activation of piezo increases cytosolic $\mathrm{Ca}^{2+}$ and release of ATP in urothelial cells [49], and several human syndromes are associated with piezo mutations. Some include Dehydrated Hereditary Stomatocytosis (DHS), Distal Arthrogyposis Type 5 (DA5), Gordon Syndrome and Marden-Walker Syndrome (MWS). In fact, piezo knockout in mice is embryonically lethal [46].

Another example of a human disease arising from loss of mechanotransduction signals is atherosclerosis. Laminar flow of blood across the apical layer of endothelial cells exert an atheroprotective effect on cells, compared with inflammatory responses triggered by turbulent flow within the vessel $[13,29,50]$. Endothelial cells in contact with blood align in the direction of shear stresses, while the orthogonal stress produces strain normal to vessel walls and stretches the vessel diameter [13]. Disturbances in blood shear (turbulent flow) cause atherosclerotic plaques in vessel walls, which narrow arteries and contribute to vascular diseases and heart failure. Altering blood flow or the inability to sense shear can affect the embryonic development of the heart [51] and cause inflammation and increased plaques in adults with cardiovascular disease risk factors (diabetes, obesity, lack of exercise and smoking) [13].

Skeletal and cardiac cells also respond to external mechanical load following Wolff's principle (sustained increase in the magnitude of applied stress on the bone enhances bone growth and remodeling [52]). In bone matrices themselves, induced pressure gradients (gravity and muscle induced contractive forces) produce deformations within the bone that drive interstitial fluids through the lacunae-canalicular network. This fluid flow induces bone remodeling and maintenance [53]. Osteoporosis and loss of bone mass result from altered fluid shear, abnormal nano-mechanical stress reception and response [54].

\section{Tools to Study Cellular Mechanotransduction}

To investigate the biophysical parameters that control cell mechanotransduction, engineers and biologists have developed different physical and molecular probes that quantitatively apply and/or detect pico-Newton forces (Figure 2).

Current bioengineered devices can generate forces that mimic inter- and intra-cellular forces produced across cell receptors. ECM properties (rheology, anisotropy, ligand density and epitope availability) determine cell deformation and stress generation [55]. Using probes customized with 
receptor ligands, the mechanosensing ability and force specificity of receptor/ligand pairs can be investigated. Depending on the directionality and type, forces can be classified into shear, tensile, compressive or oscillatory (rotatory) forces, and have been shown to induce direction specific biochemical signaling [56]. Almost all the developed force application tools are compatible with fluorescence or bright field microscope systems, enabling live cell investigation (across spatial or temporal dimensions). This report will briefly discuss the tools and forces applied in 2D ( $x-y$ plane) and the reader is advised to read other excellent articles discussing mechanotransduction effects of 3D forces [57-62].

A

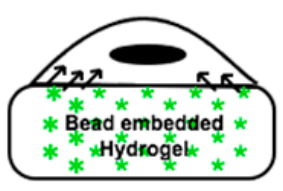

B

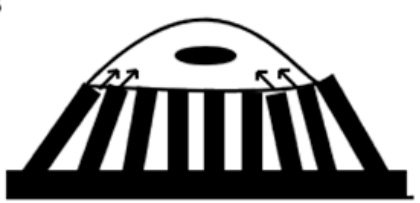

C

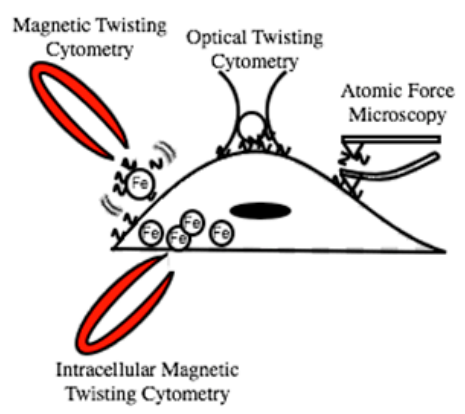

D

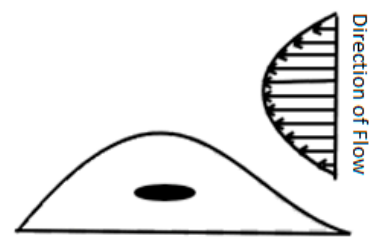

Figure 2. Common biophysical tools used to investigate mechanotransduction. (A,B) The Traction Force Microscopy set up quantifies the displacement in the substrate caused by the cell. Cells are grown on protein-functionalized (A) hydrogels embedded with fluorescent markers; or (B) micropillars with known height and elastic moduli. The deflection ( $\Delta \mathrm{l}$ of a region of the hydrogel or pillar) is indirectly used to quantify cell contractility in that zonal area; (C) Magnetic or optical twisting cytometry and atomic force microscopy are techniques that can apply pico to micro Newton shear, compressive and tensile forces on cell receptors, and cytosolic organelles; (D) Shear forces from fluid flow are investigated by growing cells on tubular or cylindrical surfaces. The apical surface of the cell experiences shear forces that is proportional to flow velocity shear rate and viscosity.

\subsection{Traction Force Microscopy (TFM)}

TFM (Traction Force Microscopy) quantitatively measures the stress exerted by a cell on its substrate environment. Each cell is continually experiencing an internal force balance between compressive and tensile elements (the tensegrity model) and is influenced by other elements in the cellular environment $[10,12,63,64]$. The force exerted by cells on the environment is indirectly reflected on the intracellular force balance (prestress) and serves as an indicator of cell contractility. The preexisting tensional stress on an element/node before any external stress is applied is defined as prestress. The features of prestress (extent of rigidity, orientation and force balance of tensile and compressive elements) determine the extent of resistance in enduring displacement (strain), while attaining new stress equilibrium configurations [63]. The material properties of the cell can also, in turn, dictate the extent of spreading and differentiation in embryonic stem cells [65].

Adherent cells exert (traction) forces on their substrate by anchoring onto specific ECM proteins. The biochemical mechanism of traction generation involves a complex interplay between adhesion molecules, cytoskeletal elements, motor proteins, enzyme activity and their respective activation or 
recruitment kinetics $[34,66,67]$. The generated cell traction is measured by averaging the magnitude of forces that induce a substrate displacement per unit area [68]. By having fiducial fluorescent markers within a flexible substrate under the cell, and tracking its position with and without the cell, the substrate displacement is quantified. There are many custom programs to calculate $2 \mathrm{D}$ bead displacement (particle image velocimetry (PIV), particle tracking-e.g., Utrack 2.0, a matlab based program from the Danuser lab, UT Southwestern). From the displacement and the elastic modulus of the gel, the traction stress is calculated using analytical solutions (such as the Boussinesq solution) in Fourier space as explained by Butler et al. [68] or using the Finite Element Method (FEM) $[69,70]$. Here, the measured traction is the root mean square of the local forces per unit area and is calculated using Fourier Transform Traction Cytometry (FTTC) as outlined above. The displacement in the $z$ direction is either negligible or ignored in 2D TFM, while the displacement in the $x$ and $y$ plane is often considered in a semi-infinite medium substrate (valid when lateral cell dimensions and displacements are smaller compared to gel thickness) [68]. Using hydrogels as substrates, the traction stresses $(\sigma)$ are related to displacements by a tensorial version of Hooke's law [71] with the known Young's modulus $(E)$ and Poisson's ratio $(v)$ of the gel. For experimental purposes, the chosen Poisson ratio is $0.48-0.5$ for polyacrylamide [72,73] and 0.5 for polydimethylsiloxane (PDMS) [74] gels.

Traction forces are generally determined for single cells or cluster of cells $[75,76]$ and the required displacement map is calculated taking stage drift into account $[62,68,77,78]$. The major disadvantage with the setup is that high throughput data collection requires fine microscope mechanical stage $x-y$ displacement with multi-dimensional data acquisition software with minimal change in the focal plane while acquiring multiple cell traction data points. Since cells are dynamic and frequently remodel (change in the contact area, adhesion strength under different cell cycle stages) it is sometimes difficult to compare traction force distributions at different time points. In a recent work, the need for removing attached cells to calculate substrate traction is avoided using well-arranged reference quantum dots onto a monocrystalline array substrate [79]. Another method to measure substrate deformations is by using a cholesteryl ester coated liquid crystal (LC) as a substrate for cells that can detect and transduce cellular traction forces [80].

Apart from using hydrogels, 2D traction forces can also be measured by growing cells on ECM functionalized micropatterned pillar substrates [76]. Each pillar can be used as a force transducing cantilever beam, by adhering cells onto ECM functionalized pillar surfaces. Cells exert traction stresses on the micropillar and cause the pillar to bend, which is then quantified. By altering the pillar height and material characteristics one can tune the modulus of rigidity of the substrate. For pillar-based studies (with known Young's modulus $(E)$, height $(L)$, diameter $(D))$ on fixed substrates, the lateral force (in the linear regime of pillar deformation $\delta$ ) at the top of pillar is given by $[81,82]$,

$$
F=\mathrm{K}_{\mathrm{bend}} \cdot \delta=\left(3 \cdot \pi \cdot E \cdot D^{4} / 64 \cdot L^{3}\right) \cdot \delta
$$

By measuring the pillar deflection (using custom tracking software), the force generated by the cell to bend the pillar is quantified. The micropillar traction technique involves discrete displacements of individual adhesion zones, while gel-based TFM involves continuous substrates. The inconvenience of the micropillar data analysis is that the cell is grown on a layer of cylindrical needle like micropillars with controlled spacing that limits the maximum focal adhesion size and the number of focal adhesions and therefore may not represent physiological substrate adhesion in these respects. The major advantage is that high throughput data acquisition and time chase experiments are simpler as initial un-deflected pillar positions are known and cells do not need to be detached from substrates to quantify traction forces.

While Traction Force Microscopy itself identifies absolute cell stresses and stress heat maps for single cells or cell clusters, TFM in combination with cell imaging has been used to track and correlate changes in cytoskeletal and associated signals with cell mobility $[83,84]$, directionality of migration $[58,60,82,85]$, heterogeneity of cell traction associated with proliferation $[82,86]$ and stem cell fate $[31,87,88]$. 


\subsection{Magnetic Twisting/Pulling Cytometry (MTC/MPC)}

Magnetic twisting cytometry (MTC) is a well-established method to study the mechanical properties of living cells by applying a quantified external stress on a cell and measuring appropriate displacement parameters [12,65,89-93]. The 2D MTC setup consists of a horizontal and vertical Helmholtz coil around a mechanical stage $[10,12]$. The current flowing through the coil is controlled using an electronic controller, which modulates the magnetic field. Specific protein or peptide coated ferromagnetic microbeads are attached to the apical surface of the cell. The beads are magnetized by applying a strong and short magnetic pulse ( $1000 \mathrm{G}$ for less than 0.5 milliseconds). Following magnetization, a weak twisting field (much lower than the initial magnetizing field, ensures the beads will not be re-magnetized) is applied in the orthogonal direction using a vertical Helmholtz coil to the magnetic moment of the bead. As a result, the bead will attempt to align in the direction of the applied field, and due to partial embedment of the bead on the cell surface, the rotation of the bead is restricted. Therefore, such induced rotation will exert an out-of-plane shear stress. The degree of rotation is dependent on the cellular properties. It is to be noted that MTC induced shear stress can stimulate localized deformations within the cytoskeleton without disturbing the whole cell. On soft cells with some degree of bead embedment, there will be a larger bead displacement, while on stiffer cells, the resulting displacement will be small. By tracking bead displacement while applying external stress to the cell, MTC allows the measurement of cellular mechanical properties in live cells in real time. By regulating the amplitude and frequency of current passing through the coils, one can control the amount of shear stress on the cell surface. The magnetic field-induced bead displacement is tracked using a bead tracking software from which the complex modulus $\left(\mathrm{G}^{*}\right)$ is computed. Measuring the phase lag between the input current in the coil and the resultant displacement allow the determination of G' (elastic modulus) and G" (viscous modulus) of the cell.

Magnetic pulling cytometry (MPC) works on a similar principle as MTC, except that a superparamagnetic bead is used. As the name suggests, the beads are pulled using a magnetic field and the tension induced bio-mechanochemical responses on cell receptors is investigated [94-97]. Using a permanent or electromagnetically controlled magnetic needle positioned close to a cell bound superparamagnetic bead, the bead can be magnetized $[98,99]$. The distance between the magnetic needle and the superparamagnetic bead determines the force applied and needs to be calibrated with the same bead-needle distance in experimental conditions. The pulling force applied through the magnetic needle is often calibrated by applying force on a bead embedded in a viscous fluid and by using the Stokes equation for low Reynolds number flow (force $=3 \pi \eta D v$, where $\eta$ is viscosity, $D$ is bead diameter, $v$ is bead velocity) [94]. The bead displacement is tracked optically. The magnetic pulling force can be applied for longer durations from minutes to days (to investigate longer period cellular morphological changes), supplemented with a broader magnetic field gradient by altering the magnetic strength or distance between needle and bead [98].

To specifically attach the magnetic bead to specific cell receptors, a magnetic bead with a surface exposed carboxyl or thiol group is covalently coupled to receptor ligands using specific tagging chemistry (for example free amines in protein ligands are linked to carboxyl beads using 1-Ethyl-3-[3-dimethylaminopropyl]carbodiimide (EDC), N-hydroxysuccinimide (NHS) chemistry) $[12,18,100]$. The major advantage of the MTC and MPC setup is that it can be optimized for high throughput data collection. The inconvenience is that the setup requires finely calibrated and magnetic field control equipment. Since commercially obtained magnetic beads can be of non-uniform sizes, the ligand functionalization chemistry needs to be optimized for uniform density coverage.

\subsection{Optical Tweezers}

Originally developed for trapping atoms and molecules [101,102], optical tweezers have emerged as one of the important tools in biophysics research and have facilitated mechanistic single molecule studies in biology. Some of the seminal works carried out with optical tweezers with single molecule perturbation and resolution involves myosins [103-105], kinesins [105-107], 
dyneins [108-110], bacterial flagellar motors [111,112], DNA and RNA mechanics and related protein interactions [113-120]. Optical tweezers have also been widely used in cell studies [121-123] and in calibrating single molecule force sensors for cellular force spectroscopy [124-126].

The working principle of optical tweezers relies on the force induced by a laser beam focused onto small dielectric beads. The slimmest region of the focused beam encloses the strongest electric field gradient and traps the dielectric particles. Exploiting the law of conservation of momentum, the highly focused beam cause the bead to experience a force in the direction of the beam. This force (called the scattering force) pushes the bead along the direction of beam propagation. The second force the bead experiences emerges from the gradient force arising from the gradient of field intensity. 3D manipulation of the bead is possible by using these gradient and directional forces, which depend on the type of laser used. Specific details of the bead trapping mechanisms applied in biology are found elsewhere [127-129].

Forces produced by optical tweezers are within the range of 0.1 pico newton $(\mathrm{pN})$ to $\sim 100 \mathrm{pN}$ [130], which makes it ideal for cellular and molecular level force probe applications. High-resolution optical traps are sensitive enough to measure nanometer scale displacement with micrometer size beads [131]. As a result, optical tweezers are an ideal tool for manipulating a bead attached to either DNA, proteins or enzymes.

For whole cell studies, the beads were coated with a ligand of choice to specifically target receptors of interest on the cell surface. Once the bead is attached to a cell, the laser beam can be used to manipulate the bead attached to the cell surface. It is worth mentioning that the functionality of optical tweezers can be further improved by combining it with detection techniques such as confocal fluorescence, Förster resonance energy transfer (FRET), fluorescence lifetime imaging microscopy (FLIM), stimulated emission depletion (STED) or Raman [129].

\subsection{Atomic Force Microscopy (AFM)}

AFM (Atomic Force Microscopy, also known as scanning probe microscopy), like MTC, can be used to apply a controlled amount of force (pico to nano Newton level forces) on the cell surface. In AFM, a cantilever with a tip at one end is used to probe the cell. The displacement in the $z$ direction of the cantilever is measured using a laser that reflects off the back surface of the cantilever beam. If the spring constant of the cantilever is softer than the surface being probed, the cantilever bends and the deflection is measured using a position sensitive detector. The cantilever beam bends when the tip shears or pulls on molecules that resist $z$-axis displacement or on completely extended cellular receptors, and in advanced systems, force-induced twist (angular twist) of the beam is also monitored. The calibrated cantilever often has a functionalized tip that carries a ligand (example RGD peptide to apply forces on integrin receptors on cells). By altering the ligand, forces can be applied specifically on certain cellular receptors. To probe biological samples, wet mode AFM is used where the kinetics of binding, unfolding and folding events can be monitored while the receptor is being sheared $[20,132,133]$.

The three modes of AFM are contact mode, intermittent contact mode, and non-contact mode. In biological samples, probe tip extension and/or shear on bound cellular receptors produces surface shear in contact mode. The force-indentation curve (applied force vs. distance of the tip from the sample surface) is often fitted to a Hertz model of contact mechanics. Force curves reflect receptor properties of adhesion, elasticity, and bond rupture strengths [134]. The elasticity of the local tip-receptor interaction is calculated from the slope of beam deflection to tip displacement. The stiffness of the material (local volumetric region experiencing and resisting shear around the cell receptor) is measured as the ratio of applied force over strain along the direction of force. The forces are normalized to contact area to minimize the influence of material geometry on stiffness. For a perfectly elastic material, the linear relationship of strain and stress is given by Hooke's law, $\sigma=E \cdot \varepsilon$; where $\sigma$ is the applied stress ( $\sigma=$ Force/contact area), $E$ is Young's modulus of elasticity, $\varepsilon$ is produced strain (dl/l). In AFM 
compression experiments, using a spherical tip, when the applied force varies linearly with surface displacement, the applied force $P$ is given by

$$
P=\frac{4 E}{3\left(1-v^{2}\right)} \sqrt{R} \delta^{3 / 2}
$$

where $E$ is elastic modulus, $R$ is the radius of the indenter, $\delta$ is indentation depth and $v$ is the Poisson ratio for the material [135].

AFM can be modified to study single molecule experiments [20], where extension and conformation changes can be coupled with FRET pairs and the forces and strain within a molecule can be calibrated in tandem [18,124]. AFM has also been used to stretch biomolecules that involve intra-domain unfolding mechanisms with multiple conformations $[133,136,137]$. AFM has also been used to monitor the extent of modular trans/cis interaction and bond strength [138], association and dissociation rates [139], directionality of stretch [140], phosphorylation levels [141] and electrostatic potential at biological surfaces [142].

\subsection{Shear Flow Microfluidic Devices}

Parallel plate flow chamber experiments with endothelial cells have shown that shear flow can align cells [50,143-148]. To understand the influence of fluid shear, and to exert better control of the direction of shear and simultaneously monitor shear-induced changes efficiently, different microfluidic flow chambers have been designed. These devices apply a variety of mechanical stimuli like shear, stiffness gradients, confined zones, interstitial flow mimics and cell stretching [149-153]. For example, Song et al. developed a multi-compartment shear flow microfluidic platform using a braille piezoelectric array of pins that functions as valves with a multi-step peristaltic pumping sequence $[149,154]$. The channels control the shear stress by controlling the flow rate (volume displacement by the pump), which is indirectly controlled by the frequency of pumping sequence (braille pin movement). Using this setup, Song et al. [154] investigated the change in the angle of cell orientation and shape index (degree of roundness) by visualizing endothelial cell morphology (cell elongation and orientation). Another design mimicking interstitial forces between capillaries and tissues was built using a multi-channel microfluidic device that could effectively control hydrostatic pressures across an endothelial cell layer [149,151]. Cells were grown in 3D scaffold hydrogels assembled between two microchannels. The surface shear and interstitial forces (perpendicular to the cell plane) were controlled by regulating the cell growth media volume in the reservoir microchannels [151].

To quantify stretching (strain) effects on cells, microfluidic devices that can stretch cell substrates have been designed [152]. Here, a flexible and porous PDMS substrate sandwiched between two other PDMS layers adjoined by two vacuum chambers has been used to apply cyclic strain and stretch on bound cells (by regulating the magnitude and frequency of the vacuum and thus indirectly straining PDMS substrate). Another example is the physical application of uniaxial [155-157], biaxial [158] or equibiaxial $[159,160]$ strain on cells by directly stretching their hydrogel supports. Confinement effects have also been studied using microfluidic channels that spatially control the 2.5D to 3D environment [153]. Confinement effects can directly assess the effect of confinement on cancer cell metastasis [150].

\section{Adhesion Receptors that Transduce Force}

The characteristic feature distinguishing multicellular organisms from unicellular ones is their ability to form functional multicellular aggregates—tissues with intercellular networks. Epithelial cells form 2D monolayers and can sense their external chemical and physical environment using specific membrane-associated receptors $[4,15,34]$. These receptors serve as bio-molecular antennas, receiving and transducing external chemical (ligand) and physical (mechanical, electrical) stimuli $[8,161]$. 
The hallmark of mechanotransduction is the cell's biochemical adaptability to respond to external mechanical stimuli. This dynamic ability is regulated by the specificity of the receptor transducing the force [17,162-164], the activated mechano-biochemical pathway and the induced secondary messenger elements $[11,18,27,56]$. The kinetics of receptor-ligand binding [164-166], shear induced reactions $[18,156,167,168]$ and pathways activated $[23,143,168-175]$ are still being investigated using advanced biophysical tools coupled with imaging and biomolecular engineering techniques.

Cells use adhesion receptors to sense substrates and neighboring cells. The dominant cell adhesion receptors include cadherins [176,177], integrins [172,178,179], immunoglobulin-like Cell Adhesion Molecules (ICAM) [179], and selectins [34]. The cadherin protein family comprises essential cell-cell adhesion proteins, and the integrin family forms cell-extracellular matrix adhesions. Here, we focus on the mechanotransduction pathways of cadherin and integrin receptors in epithelial cells.

\subsection{Integrin-The Primary Cell-Matrix Adhesion Molecule}

Integrins enable cells to adhere and spread on extracellular matrices $[172,180]$. Each integrin receptor is a cis-heterodimer of $\alpha$ and $\beta$ transmembrane proteins [172,181]. There is a total of 18 reported isoforms of $\alpha$, and 8 isoforms of $\beta$ receptors, and each specific $\alpha-\beta$ heterodimer can recognize one or more ECM protein [181]. The extracellular $\mathrm{N}$-terminal region of the $\alpha$ receptor has an I domain (present in some $\alpha$ subunit isoforms), a seven-bladed $\beta$ propeller domain, a thigh domain and the calf 1 and calf 2 domains. The extracellular $N$-terminal region of the $\beta$ receptor has a $\beta$ I like domain, a hybrid domain, cysteine rich plexin-semaphoring-integrin (PSI) domain, $\beta$ sandwich domain, 4 epidermal growth factor (EGF)-like repeats and a $\beta$ tail domain [172]. With the many isoforms of $\alpha$ and $\beta$ receptors, there is a total of 24 known integrin $\alpha-\beta$ heterodimers that recognize specific extracellular matrix (ECM) molecules $[182,183]$. The dominant integrin recognized ECM proteins include fibronectin (RGD, LDV), collagen isoforms I and IV (GFOGER), laminin isoforms (YIGSR), vitronectin (RGD), fibrinogen (RGD), thrombospondin (RGD, NVR, LDVP), and other glycoproteins [184].

Among integrin ligands, the RGD peptide is the best characterized and most studied, with a third of functional integrin isoforms recognizing the RGD domain $[181,185,186]$. The RGD domain is found in multiple ECM proteins and is recognized by $\alpha 5 \beta 1, \alpha \mathrm{V} \beta 3, \alpha \mathrm{V} \beta 1, \alpha \mathrm{V} \beta 5, \alpha \mathrm{V} \beta 6, \alpha \mathrm{V} \beta 8$, and $\alpha \operatorname{Ilb} \beta 3$ integrin heterodimers, laminin isoforms are recognized by $\alpha 1 \beta 1, \alpha 2 \beta 1, \alpha 3 \beta 1, \alpha 6 \beta 1, \alpha 7 \beta 1$ and $\alpha 6 \beta 4$, and collagen isoforms are recognized by $\alpha 1 \beta 1, \alpha 2 \beta 1, \alpha 3 \beta 1, \alpha 10 \beta 1$, and $\alpha 11 \beta 1[179,181,182]$. Since integrins are capable of binding to multiple ECM peptides, it is the level of surface expression, relative ligand availability, affinity and trans-domination among the isoforms that determine the subtype of integrin-ECM adhesion [17,180,187]. Integrins have 2 major functional conformations that relate its affinity to ECM ligand: the inactive low affinity or bent conformation and the ligand bound high-affinity or extended conformation. Using FRET probes, a separation of $5 \mathrm{~nm}$ was observed between $\alpha$ and $\beta$ stem domains (under $\mathrm{Mn}^{2+}$ stimulated active state) [188] while cryoelectron tomography studies did not detect any significant height changes (on integrin $\alpha_{\text {II }} \beta_{3}$ activation [189]). The bent form (bent at an angle of $135^{\circ}$, between I-EGF-1 and EGF2 domain of $\beta$ subunit) is inactive with its inability to bind to ligand (lower affinity structure) [190]. Exposure of receptor epitopes that interact with the ligand is higher in the upright conformation (higher affinity structure). Integrins, upon activation, provide an intracellular scaffold for the assembly of cytosolic signaling complexes. These intracellular signaling events that follow extracellular stimulation are commonly described as "outside-in" signaling events (compared to intracellular events that lead to integrin activation, called "inside-out" signaling) [190]. The biochemical events controlling integrin-cytoskeleton interactions have implications in many cellular processes like cell migration, membrane protrusion, proliferation, cancer metastasis, immune cell invasion, and apoptosis, among others. 


\subsubsection{Focal Adhesions}

New integrin adhesions (nascent focal adhesions) that form from lamellipodial membrane extensions are very dynamic and contain talin and paxillin in the nascent complex [66]. Clustering of integrin receptors and the assembly of the adhesion complex enhance cell adhesion strength $[173,191]$. Talin serves as an actin tethering site, and the maturation of nascent adhesion complex forms focal complexes (FX) [192]. In addition to nascent adhesion complex proteins, FX includes a $100 \mathrm{~nm}$ diameter cluster complex that houses active vinculin, focal adhesion kinase (FAK), Src family kinases (SFK), $\alpha$-actinin, actin related protein 2 -actin related protein 3 complex (Arp2/3), and vasodilator-stimulated phosphoprotein (VASP) [192]. Mature focal adhesions (FA) contain active zyxin and tensin molecules in addition to focal complex components [192,193]. Initial nascent adhesions have low levels of vinculin and focal adhesion kinase with short actin interconnections. Vinculin activation and consequent binding to talin enables another connection between the integrin-ECM and the actin cytoskeleton [169,194]. As the actin fibers are reinforced with actomyosin-based contractility elements, the nascent adhesion matures and grows into a focal adhesion [66,195,196]. Maturation of focal adhesion is also associated with the accumulation of $\alpha$-actinin in the complex that crosslinks actin filaments [197], and activation of RHO GEFs (LARG, GEF H1), which mediate myosin contraction through ROCK [162,198-200]. The literature highlighting the recruitment and activation of specific molecules at focal adhesions (which regulate cell morphology, signaling and behavior) is excellently tabulated in this article [201].

\subsubsection{Integrin's Ability to Transduce Force}

The role of cellular tension in modulating integrin function, integrin-actin linkage, and integrin-ECM adhesion has been extensively investigated [166,202]. The tension in and maturation of FX recruits talin and vinculin [192], which modulates the integrin mechanotransduction process through actin linkages [203]. The integrin mechanosensing process begins with cell adhesion and recognition of a substrate. Lamellipodial extensions occur via branched actin protrusions (force from actin polymerization pushes the membrane outward). Actin is linked to integrins through talin [204] and vinculin [124,205], and the myosin-generated actin tensile force is transmitted through integrins, which can indirectly induce conformation changes in ECM proteins [163]. The force range of integrin clusters within focal complexes was found to be above $54 \mathrm{pN}$ using single molecule integrin tension sensors, while the tension in nascent complexes was $\sim 40 \mathrm{pN}$ [206].

Myosin-dependent traction forces modulate integrin's role in sensing the substrate [207]. On soft ECM substrates, there is a lower density of actin stress fibers in cells, and reduced force across the ECM-integrin-cytoskeleton link [124,163]. The cortical actin filaments and integrin adhesions are nominally perpendicular to one other and force transmission from the actin cytoskeleton to the integrin complex is enabled by components that form a clutch [54]. Under high intracellular myosin-mediated contractility, actin moves backward (retrograde motion) [207] and transmits tensile force to integrins, which then pulls on the ECM (substrate). On harder substrates, the matrix resists the force from the cell and integrins remain relatively immobile, while on softer substrates the matrix is deformed $[5,207]$. FA complexes exhibit dynamic traction forces and the role of FAK, paxillin, and vinculin in the complex is essential for cell migration and rigidity sensing [207]. Integrins outside focal adhesions also exert traction forces, and using special multiplexed integrin tension gauge tethers, the exerted forces were found to be in the range of $43-54 \mathrm{pN}$, which was significantly lower than tensions within FA clusters [208].

Focal adhesions are associated with many signaling molecules on the cytoplasmic side [209]. Focal Adhesion Kinase (FAK) is a membrane-associated tyrosine kinase, and its activity is coupled with focal adhesion activity and maturation $[173,201,210]$. FAK is reported to regulate focal adhesion turnover, cell migration, crosstalk between growth factors and other integrin complexes [209-211]. FAK activation is a multistep process [212]-FAK is transiently activated (autophosphorylated at Y397) by integrin clustering and recruits SH2 binding Src kinase which phosphorylates Y576-577 
and increases FAK activity 20 -fold $[209,210,213]$. FAK is also reported to be biophysically activated by ECM, ligand density and substrate stiffness [163]. FAK can also phosphorylate and activate Src, and Src is reported to be active at integrin junctions [11,23,76,209]. Src has also been reported to be mechanically activated under integrin shear [92] and growth factor stimulation [214,215]. As to the Rho GTPases, Rac is associated with lamellipodial extension and actin protrusion at the membrane [216], while the Rho GEFs, namely LARG and GEF-H1, are activated indirectly by Rho kinase $[162,198,199]$. ROCK (Rho associated kinase) indirectly activates actomyosin-based contractility by inhibiting the phosphatase activity of MLCK phosphatase [199,217]. Cdc42 reportedly suppresses Rho GTPase activity and relieves intracellular tension, avoiding stress-induced detachment of cell-cell adhesions $[11,218]$. Rac and Rho activity are reciprocally correlated to contractility and actin dynamics in lamellipodial extension [219].

The temporal and spatial activity of the aforementioned FA-related kinases are currently being investigated in the context of mechanotransduction [23,92,162]. Since the complex network of kinases is spatially and temporally regulated in different activation states, the population average of active and inactive kinases needs to be controlled in respective assays. Normalization ( \pm stimuli) of whole population averaged results may not be directly comparable since the relative change in kinase activity is time and location dependent. Different cell lines vary in the endogenous level of kinase activity and this may affect comparing results from cells of different tissue origin, mutations, and pathway modifications. Currently, calibratable kinase reporter assays with real-time quantification of results are used to decode the activation and functionality of kinases under specific stimuli $[18,163,214,220,221]$.

\subsection{Cadherin-The Primary Calcium Dependent Cell-Cell Adhesion Molecule}

Cell-cell adhesion is mediated by many adhesive receptors through lateral non-covalent interactions between neighboring cells [161]. The classical cadherin family of receptors dominates these lateral interactions, forming adherens junctions in epithelial cells. Tight junctions (claudin and occludin), gap and other desmosomal junction proteins are also present at lateral cell-cell contacts $[18,177,222-224]$, but their role in mechanotransduction is not completely elucidated.

Cadherin has been well established as a cell-cell adhesion molecule, and with the advancement of biomechanical adhesion tools, new biomechanical functions of cadherin have been reported [100,225-227]. Cadherin is a single pass transmembrane protein, and the cadherin subfamily includes classical type 1, atypical type 2, desmosomal, protocadherins, Flamingo/Celsr, and Dachsous and Fat cadherins $[35,177,228,229]$. Here, we focus on the role of E-cadherin (a classical type 1 Cadherin) in mechanotransduction. E-cadherin has 5 extracellular domains (EC1-5), a transmembrane domain, and a cytosolic domain. The extracellular EC1-5 domains form active cis and trans adhesion complexes in the presence of calcium $[177,230,231]$. The juxtamembrane portion of cadherin interacts with p120 catenin [232], and the cytosolic domain ( $\sim 76$ amino acids) contains a direct binding site for $\beta$ catenin $[226,233,234]$, which in turn binds with $\alpha$-catenin and allows the cadherin complex to indirectly associate with the actin microfilament $[18,100,235,236]$. The $\mathrm{N}$-terminal end of $\alpha$-catenin binds $\beta$-catenin, and the C-terminal of $\alpha$-catenin binds with actin $[100,235]$. Microtubules are also reported to be associated with adherens junctions through the PLEKHA-NEZHA complex [237].

$\alpha$-Catenin is a multi-helical repeat molecule. It has an autoinhibited $\mathrm{M}$ region between residues 376 to 633 [238] which is exposed to tension and myosin II activation [18,235,239]. The 906 amino acid long $\alpha$-catenin shares functional and sequence homology with vinculin [240]. The major $\alpha$-catenin domains are the $\mathrm{N}$-terminal $\beta$-catenin binding domain ((57-146), a self-binding region (82-264)), M domain (376-633), and a C-terminal domain (697-906, binds to actin) [240,241]. There exists a serine-threonine responsive casein kinase (CK1, CK2) substrate within a phospho-linker region ( $\mathrm{M}$ domain and $\mathrm{C}$-terminal of $\alpha$-catenin) that is reported to aid cell migration and wound closure [242]. Studies have shown that $\alpha$-catenin can form a homodimer [227] and also has binding sites for actin and actin-binding molecules such as epithelial protein lost in neoplasm (EPLIN), vinculin, afadin, $\alpha$-actinin, ZO-1, formin and zyxin $[170,239,240,243]$. The molecule can 
potentially recruit more actin fibers to cadherin junctions but requires actomyosin tension to unfurl and recruit vinculin $[18,20,24,236]$. The in vitro reconstitution of the actin- $\alpha$-catenin- $\beta$-catenin-cadherin complex (without lateral actomyosin forces) revealed the biochemical inability of $\alpha$-catenin to simultaneously interact with actin and $\beta$-catenin $[227,244]$. In vivo studies using time-resolved FRET and immunofluorescence [18,100], drosophila embryos experiments [239], and electron tomography experiments [236] showed that $\alpha$-catenin can simultaneously interact with actin and $\beta$ catenin at cadherin junctions under tension. This conundrum of opposing $\alpha$-catenin in vivo and in vitro functions identified in the previous decade $[227,233,243-248]$ was resolved recently using single molecule force probes and kinetic assays [245].

Vinculin is another molecule that aids cadherin adhesive activity. It is well known that vinculin shares sequence and structural homology with $\alpha$-catenin [240], and binds to $\alpha$ catenin at the modulatory $\mathrm{M}$ domain [24,100,171,235]. Vinculin is directly recruited and activated in cadherin mechanotransduction $[18,24,100]$, and is also studied as an actin linker protein at focal adhesions [205,249]. Its internal auto-inhibited domain is similar to that of $\alpha$-catenin [168], which is activated through force and ligand-dependent activation [124]. Vinculin's role at focal adhesion and cadherin junctions has raised the possibility that vinculin can regulate the crosstalk between adhesion receptors and global mechanotransduction [24,169,170]. Force dependent increase in actin and actin-associated protein recruitment, with improved cadherin junctional rigidity is known as the cadherin mediated cell junctional stiffening response. The multiple ways by which cadherin can associate with actin possibly showcases the ability of cells to control adherens junction rigidity and mechanosensitivity, depending on the context.

Cell-cell adhesions resist intracellular contractile tension, protrusive forces from the membrane and extracellular forces on the cell. Like integrins, cadherins are also associated with actin (through catenins) and tension across adherens junctions is modulated by actomyosin-mediated contractility [50,250]. C- (Compaction stage), N- (neural), E- (epithelial) and VE- (vascular endothelial) cadherins exhibit local actin dependent junction remodeling and increased junction stiffness following cadherin-receptor perturbation $[100,251]$. The response of cadherin complexes to intracellular and external stress demonstrates that they are mechanosensors [252,253]. C2C12 myogenic cells (that have N-cadherin receptors) and Madin-Darby canine kidney (MDCK) epithelial cells (that have E-cadherin receptors) can specifically sense and respond to extracellular forces through respective Nand E-cadherin functionalized substrates or beads [24,251]. Cadherin mechanotransduction is also ligand-specific. $\alpha$-catenin, vinculin, and actin get specifically activated and/or recruited in response to cadherin mechanotransduction $[18,50,100]$.

The global time-resolved downstream molecular cascades regulating cadherin mechanotransduction are yet to be completely elucidated. In the model detailed by Yonemura et al. [235], $\alpha$-catenin unfurls in response to increased tension on cadherin complexes, allowing actin engagement through vinculin recruitment $[18,235]$. In vitro experiments with E-cadherin and $\alpha$-catenin FRET sensor expressing epithelial cells showed that $\alpha$-catenin, vinculin, activated growth factor receptor, ligand specific interaction and actomyosin tension are required for cadherin-mediated stiffening response $[18,24,236,254,255]$. Cadherin activation with calcium, ligand-specific homophilic adhesion, cadherin cis or trans clustering, and conformation bond specific shear have been shown to activate downstream cadherin signals through Rho GTPases (Rac, Rho, Cdc42), Src, PI3K, FAK family of kinases [76,162,218,256-258], and respective protein tyrosine phosphatases [259-261]. The modulation of the spatial and temporal activity of these signaling molecules specifically due to cadherin mechanotransduction remains to be fully elucidated [199,218,257,261-263]. Cadherin malfunction and impaired mechanotransduction are involved in cardiomyopathies, vascular permeability deregulation, and lung injury among others [37,110,160,264-266]. 


\subsection{Global Mechanotransduction}

Mechanotransduction studies often rely on analyzing biochemical changes at the vicinity of the mechanical perturbation. Although the readout is measured at the site of applied forces, the specificity of the response and all the ensuing biochemical changes together define the complete mechanotransduction response. The term global mechanotransduction includes larger phenotypic cell-wide changes that occur away from the site of applied shear. Examples include a change in apical-basal cell polarity in response to fluid shear in endothelial cells [267], shear induced opening of calcium ion channels far from the site of shear [268], change in apical PECAM-1 stiffening response by altering basal integrin adhesions [162], creation of new basal focal adhesions by apical cadherin stimulation [255] and global RhoA activation under PECAM-1 shear [269]. The change in mechanical force balance between tensile (actin and intermediary filaments) and compressive (microtubule) elements in the cell (that resist and or respond to mechanical stresses $[10,270]$ ) are liable to induce global mechanical changes in the cell [271]. Collins et al. had discussed that PECAM-1 induced apical stiffening required new integrin adhesions basally [162], suggesting a biochemical regulatory phenomenon occurring away from the site of shear. These spatially and functionally isolated adhesive receptors (PECAM- 1 and integrins) were biomechanically interacting to produce a PECAM dependent stiffening response. A similar mechanism was identified with E-cadherin as well [255].

Another example of global mechanotransduction is seen in murine kidney cells, where flow induced stresses activate calcium influx through the opening of ion channels [268]. Polycystin 1 is localized at the base of the primary cilium, which undergoes conformational changes under shear and opens up the calcium ion channel (Polycystin 2) [268]. The response is amplified by further release of intracellular calcium stores. The medium of force transduction between spatially isolated receptors was described in a stress-focusing model by Hu et al., using fluorescently labeled fiducial markers in the cytosol of Human airway smooth muscle cells [271]. The molecular events underlying the rapid mechanical crosstalk between spatially isolated receptors are still being investigated and will pave the way towards understanding tissue mechanotransduction.

\subsection{Kinetic Regulation of Mechanotransduction}

The phenomenon of mechanotransduction ensures a rapid biochemical response to external mechanical stimuli. In some mechanically stimulated pathways, the transduction of mechano-biochemical events is presumably faster than protein translocation and intracellular protein diffusion, in the order of milliseconds [92]. The biochemical cascade of events that follow mechanosensing is strictly regulated by multiple proteins that, for example, require recruitment, conformational changes, activation, (de-)phosphorylation, secondary messenger activation, binding to cytoskeletal structural elements, nuclear translocation, and/or gene expression. Each event is a controlled process that modulates the rate of the mechanotransduction response. The limiting factors regulating the cascade are often investigated using biochemical mutagenesis, siRNA, chemical inhibitors, single molecule biophysical, and kinetic studies. The kinetics can get complicated when the available concentration of each substrate, the conformation specific affinities and mixed parallel reactions of substrate/product and inhibitor kinetics have to be envisioned simultaneously in response to a specific mechanical stimulation.

An example of a kinetic control element regulating cadherin mechanotransduction is $\alpha$-catenin. The actin binding kinetics of $\alpha$-catenin homodimer $(\alpha-\alpha$-catenin $)$ vs heterodimer $(\beta-\alpha$-catenin) was identified under biochemical reconstitution experiments in vitro [233,244]. $\alpha$-catenin can either exclusively bind to $\beta$ catenin or form $\alpha$-catenin homodimers in vitro, as the $\alpha-\beta$ and $\alpha$ - $\alpha$ interacting domains have overlapping binding regions [227]. In solution, the affinity for $\alpha$-catenin towards forming a homodimer is higher than $\alpha$-catenin-actin interaction, and also competes with Arp $2 / 3$ branching of actin filaments [244]. Near the cell membrane, the local concentration of actin monomers at cadherin junctions is high, promoting $\alpha$-catenin-actin interaction; and intracellular actomyosin-mediated contractile forces unfurl $\alpha$-catenin and expose actin-binding domains. Tension appears to further 
increase $\alpha$-catenin's affinity to actin and also recruits vinculin with nanomolar affinity. The pseudo first order vinculin recruitment and binding to the cadherin adhesion complex were kinetically evaluated using AFM, mutagenesis, FRET, and stretch assays $[18,20]$. The aforementioned example illustrates that kinetic studies of mechanotransduction are more involved, but can reveal a dynamic and rich cellular response to mechanical stimulation.

\section{Conclusions}

This review is structured to enable students to quickly understand the basic experimental and conceptual fundamentals related to mechanotransduction studies. In this spirit, Table 1 further summarizes other reviews that can help introduce a student to relevant concepts and tools.

Table 1. Summary of reviews.

\begin{tabular}{ccc}
\hline $\begin{array}{c}\text { Experimental Method/Aspect of } \\
\text { Mechanotransduction }\end{array}$ & $\begin{array}{c}\text { Representative } \\
\text { References }\end{array}$ & $\begin{array}{c}\text { Schematics/Tables That Explain } \\
\text { Concepts/Theory }\end{array}$ \\
$\begin{array}{c}\text { Mechanotransduction } \\
\text { Mechanotransduction diseases }\end{array}$ & {$[272,273]$} & Figure 1 from [9] and Figure 6 from [274] \\
Cytoskeletal mechanotransduction & {$[3]$} & Not applicable \\
Traction Force/Stress Microscopy & {$[68,275]$} & Figure 4 from [203] \\
Magnetic Twisting Cytometry & {$[277]$} & Figure 4 from [63] \\
Microfluidic Shear & {$[149]$} & Figure 1 from [277] \\
Comparison of force application tools & {$[55]$} & Figure 2 from [149] \\
Integrin mechanotransduction & {$[278]$} & Table 1 from [55,128] \\
Cadherin mechanotransduction & {$[177]$} & Figure 4 from [5] \\
Mechanotransduction signals & {$[28,34,176]$} & Figure 1 from [9] \& Figure 4 from [177] \\
\hline
\end{tabular}

Acknowledgments: Venkat Maruthamuthu acknowledges support from the Thomas F. and Kate Miller Jeffress Memorial Trust and the NIH (1R15GM116082). Farhan Chowdhury acknowledges the support of Elevated Research 2.0 seed grant from Southern Illinois University Carbondale. We acknowledge Daniel Chester and Joseph G Squires for assisting in proof reading the article.

Conflicts of Interest: The authors declare no conflict of interest.

\section{References}

1. Guilak, F.; Cohen, D.M.; Estes, B.T.; Gimble, J.M.; Liedtke, W.; Chen, C.S. Control of stem cell fate by physical interactions with the extracellular matrix. Cell Stem Cell 2009, 5, 17-26. [CrossRef] [PubMed]

2. Chen, C.S. Mechanotransduction-A field pulling together? J. Cell Sci. 2008, 121, 3285-3292. [CrossRef] [PubMed]

3. Ingber, D.E. Mechanobiology and diseases of mechanotransduction. Ann. Med. 2003, 35, 564-577. [CrossRef] [PubMed]

4. Schwartz, M.A.; DeSimone, D.W. Cell adhesion receptors in mechanotransduction. Curr. Opin. Cell Biol. 2008, 20, 551-556. [CrossRef] [PubMed]

5. Humphrey, J.D.; Dufresne, E.R.; Schwartz, M.A. Mechanotransduction and extracellular matrix homeostasis. Nat. Rev. Mol. Cell Biol. 2014, 15, 802-812. [CrossRef] [PubMed]

6. Ingber, D.E. Cellular mechanotransduction: Putting all the pieces together again. FASEB J. 2006, $20,811-827$. [CrossRef] [PubMed]

7. Han, B.; Bai, X.-H.; Lodyga, M.; Xu, J.; Yang, B.B.; Keshavjee, S.; Post, M.; Liu, M. Conversion of mechanical force into biochemical signaling. J. Biol. Chem. 2004, 279, 54793-54801. [CrossRef] [PubMed]

8. Wang, N.; Tytell, J.D.; Ingber, D.E. Mechanotransduction at a distance: Mechanically coupling the extracellular matrix with the nucleus. Nat. Rev. Mol. Cell Biol. 2009, 10, 75-82. [CrossRef] [PubMed]

9. Smutny, M.; Yap, A.S. Neighborly relations: Cadherins and mechanotransduction. J. Cell Biol. 2010, 189, 1075-1077. [CrossRef] [PubMed] 
10. Wang, N.; Naruse, K.; Stamenović, D.; Fredberg, J.J.; Mijailovich, S.M.; Tolić-Nørrelykke, I.M.; Polte, T.; Mannix, R.; Ingber, D.E. Mechanical behavior in living cells consistent with the tensegrity model. Proc. Natl. Acad. Sci. USA 2001, 98, 7765-7770. [CrossRef] [PubMed]

11. Weber, G.F.; Bjerke, M.A.; DeSimone, D.W. Integrins and cadherins join forces to form adhesive networks. J. Cell Sci. 2011, 124, 1183-1193. [CrossRef] [PubMed]

12. Wang, N.; Butler, J.P.; Ingber, D.E. Mechanotransduction across the cell surface and through the cytoskeleton. Science 1993, 260, 1124-1127. [CrossRef] [PubMed]

13. Hahn, C.; Schwartz, M.A. Mechanotransduction in vascular physiology and atherogenesis. Nat. Rev. Mol. Cell Biol. 2009, 10, 53-62. [CrossRef] [PubMed]

14. Kamkin, A.; Kiseleva, I. Mechanosensitivity in Cells and Tissues. In Academia; Springer: New York, NY, USA, 2005.

15. Bershadsky, A.D.; Balaban, N.Q.; Geiger, B. Adhesion-dependent cell mechanosensitivity. Annu. Rev. Cell Dev. Biol. 2003, 19, 677-695. [CrossRef] [PubMed]

16. Xiao, R.; Xu, X.Z.S. Mechanosensitive channels: In touch with Piezo. Curr. Biol. 2010, 20, R936-R938. [CrossRef] [PubMed]

17. Orr, A.W.; Ginsberg, M.H.; Shattil, S.J.; Deckmyn, H.; Schwartz, M.A. Matrix-specific suppression of integrin activation in shear stress signaling. Mol. Biol. Cell 2006, 17, 4686-4697. [CrossRef] [PubMed]

18. Kim, T.-J.; Zheng, S.; Sun, J.; Muhamed, I.; Wu, J.; Lei, L.; Kong, X.; Leckband, D.E.; Wang, Y. Dynamic Visualization of $\alpha$-Catenin Reveals Rapid, Reversible Conformation Switching between Tension States. Curr. Biol. 2014, 25, 218-224. [CrossRef] [PubMed]

19. Lecuit, T. Alpha-catenin mechanosensing for adherens junctions. Nat. Cell Biol. 2010, 12, 522-524. [CrossRef] [PubMed]

20. Yao, M.; Qiu, W.; Liu, R.; Efremov, A.K.; Cong, P.; Seddiki, R.; Payre, M.; Lim, C.T.; Ladoux, B.; Mège, R.-M.; et al. Force-dependent conformational switch of $\alpha$-catenin controls vinculin binding. Nat. Commun. 2014, 5, 4525. [CrossRef] [PubMed]

21. Riveline, D.; Zamir, E.; Balaban, N.Q.; Schwarz, U.S.; Ishizaki, T.; Narumiya, S.; Kam, Z.; Geiger, B.; Bershadsky, A.D. Focal contacts as mechanosensors: Externally applied local mechanical force induces growth of focal contacts by an mDia1-dependent and ROCK-independent mechanism. J. Cell Biol. 2001, 153, 1175-1186. [CrossRef] [PubMed]

22. Martinez-Rico, C.; Pincet, F.; Thiery, J.-P.; Dufour, S. Integrins stimulate E-cadherin-mediated intercellular adhesion by regulating Src-kinase activation and actomyosin contractility. J. Cell Sci. 2010, 123, 712-722. [CrossRef] [PubMed]

23. Wang, Y.; Botvinick, E.L.; Zhao, Y.; Berns, M.W.; Usami, S.; Tsien, R.Y.; Chien, S. Visualizing the mechanical activation of Src. Nature 2005, 434, 1040-1045. [CrossRef] [PubMed]

24. Le Duc, Q.; Shi, Q.; Blonk, I.; Sonnenberg, A.; Wang, N.; Leckband, D.; de Rooij, J. Vinculin potentiates E-cadherin mechanosensing and is recruited to actin-anchored sites within adherens junctions in a myosin II-dependent manner. J. Cell Biol. 2010, 189, 1107-1115. [CrossRef] [PubMed]

25. Trichet, L.; Le Digabel, J.; Hawkins, R.J.; Vedula, S.R.K.; Gupta, M.; Ribrault, C.; Hersen, P.; Voituriez, R.; Ladoux, B. Evidence of a large-scale mechanosensing mechanism for cellular adaptation to substrate stiffness. Proc. Natl. Acad. Sci. USA 2012, 109, 6933-6938. [CrossRef] [PubMed]

26. Collins, C.; Tzima, E. Rac[e] to the pole: Setting up polarity in endothelial cells. Small GTPases 2014, 5, e28650. [CrossRef] [PubMed]

27. Weber, G.F.; Bjerke, M.A.; DeSimone, D.W. A mechanoresponsive cadherin-keratin complex directs polarized protrusive behavior and collective cell migration. Dev. Cell 2012, 22, 104-115. [CrossRef] [PubMed]

28. Provenzano, P.P.; Keely, P.J. Mechanical signaling through the cytoskeleton regulates cell proliferation by coordinated focal adhesion and Rho GTPase signaling. J. Cell Sci. 2011, 124, 1195-1205. [CrossRef] [PubMed]

29. Jaalouk, D.E.; Lammerding, J. Mechanotransduction gone awry. Nat. Rev. Mol. Cell Biol. 2009, 10, 63-73. [CrossRef] [PubMed]

30. Shen, X.; Kramer, R.H. Adhesion-mediated squamous cell carcinoma survival through ligand-independent activation of epidermal growth factor receptor. Am. J. Pathol. 2004, 165, 1315-1329. [CrossRef]

31. Swift, J.; Ivanovska, I.L.; Buxboim, A.; Harada, T.; Dingal, P.C.; Pinter, J.; Pajerowski, J.D.; Spinler, K.R.; Shin, J.W.; Tewari, M.; et al. Nuclear lamin-A scales with tissue stiffness and enhances matrix-directed differentiation. Science 2013, 341, 1240104. [CrossRef] [PubMed] 
32. Jeanes, A.; Gottardi, C.J.; Yap, A.S. Cadherins and cancer: How does cadherin dysfunction promote tumor progression? Oncogene 2008, 27, 6920-6929. [CrossRef] [PubMed]

33. Park, J.; Kim, P.; Helen, W.; Engler, A.J.; Levchenko, A.; Kim, D.-H. Control of stem cell fate and function by engineering physical microenvironments. Integr. Biol. 2012, 4, 1008-1018.

34. Juliano, R.L. Signal transduction by cell adhesion receptors and the cytoskeleton: Functions of integrins, cadherins, selectins, and immunoglobulin-superfamily members. Annu. Rev. Pharmacol. Toxicol. 2002, 42, 283-323. [CrossRef] [PubMed]

35. Niessen, C.M.; Leckband, D.; Yap, A.S. Tissue organization by cadherin adhesion molecules: Dynamic molecular and cellular mechanisms of morphogenetic regulation. Physiol. Rev. 2011, 91, 691-731. [CrossRef] [PubMed]

36. Lecuit, T.; Lenne, P.-F.; Munro, E. Force generation, transmission, and integration during cell and tissue morphogenesis. Annu. Rev. Cell Dev. Biol. 2011, 27, 157-184. [CrossRef] [PubMed]

37. Purves, D.; Augustine, G.J.; Fitzpatrick, D.; Katz, L.C.; LaMantia, A.-S.; McNamara, J.O.; Williams, S.M. Hair Cells and the Mechanoelectrical Transduction of Sound Waves. In Neuroscience, 2nd ed.; Sinauer Associates Inc.: Sunderland, MA, USA, 2001.

38. Meyer, J.; Preyer, S.; Hofmann, S.I.; Gummer, A.W. Tonic mechanosensitivity of outer hair cells after loss of tip links. Hear. Res. 2005, 202, 97-113. [CrossRef] [PubMed]

39. Corey, D.P.; Sotomayor, M. Hearing: Tightrope act. Nature 2004, 428, 901-903. [CrossRef] [PubMed]

40. Brohawn, S.G.; Su, Z.; MacKinnon, R. Mechanosensitivity is mediated directly by the lipid membrane in TRAAK and TREK1 K+ channels. Proc. Natl. Acad. Sci. USA 2014, 111, 3614-3619. [CrossRef] [PubMed]

41. Brohawn, S.G.; Campbell, E.B.; MacKinnon, R. Physical mechanism for gating and mechanosensitivity of the human TRAAK K+ channel. Nature 2014, 516, 126-130. [CrossRef] [PubMed]

42. Woo, S.-H.; Ranade, S.; Weyer, A.D.; Dubin, A.E.; Baba, Y.; Qiu, Z.; Petrus, M.; Miyamoto, T.; Reddy, K.; Lumpkin, E.A.; et al. Piezo2 is required for Merkel-cell mechanotransduction. Nature 2014, 509, 622-626. [CrossRef] [PubMed]

43. Coste, B.; Xiao, B.; Santos, J.S.; Syeda, R.; Grandl, J.; Spencer, K.S.; Kim, S.E.; Schmidt, M.; Mathur, J.; Dubin, A.E.; et al. Piezo proteins are pore-forming subunits of mechanically activated channels. Nature 2012, 483, 176-181. [CrossRef] [PubMed]

44. Ge, J.; Li, W.; Zhao, Q.; Li, N.; Chen, M.; Zhi, P.; Li, R.; Gao, N.; Xiao, B.; Yang, M. Architecture of the mammalian mechanosensitive Piezo1 channel. Nature 2015, 527, 64-69. [CrossRef] [PubMed]

45. Syeda, R.; Florendo, M.N.; Cox, C.D.; Kefauver, J.M.; Santos, J.S.; Martinac, B.; Patapoutian, A. Piezo1 Channels Are Inherently Mechanosensitive. Cell Rep. 2016, 17, 1739-1746. [CrossRef] [PubMed]

46. Volkers, L.; Mechioukhi, Y.; Coste, B. Piezo channels: From structure to function. Pflüg. Arch. 2015, 467, 95-99. [CrossRef] [PubMed]

47. Peyronnet, R.; Martins, J.R.; Duprat, F.; Demolombe, S.; Arhatte, M.; Jodar, M.; Tauc, M.; Duranton, C.; Paulais, M.; Teulon, J.; et al. Piezo1-dependent stretch-activated channels are inhibited by Polycystin-2 in renal tubular epithelial cells. EMBO Rep. 2013, 14, 1143-1148. [CrossRef] [PubMed]

48. Poole, K.; Herget, R.; Lapatsina, L.; Ngo, H.-D.; Lewin, G.R. Tuning Piezo ion channels to detect molecular-scale movements relevant for fine touch. Nat. Commun. 2014, 5, 3520. [CrossRef] [PubMed]

49. Miyamoto, T.; Mochizuki, T.; Nakagomi, H.; Kira, S.; Watanabe, M.; Takayama, Y.; Suzuki, Y.; Koizumi, S.; Takeda, M.; Tominaga, M. Functional role for Piezo1 in stretch-evoked $\mathrm{Ca}^{2+}$ influx and ATP release in urothelial cell cultures. J. Biol. Chem. 2014, 289, 16565-16575. [CrossRef] [PubMed]

50. Conway, D.E.; Breckenridge, M.T.; Hinde, E.; Gratton, E.; Chen, C.S.; Schwartz, M.A. Fluid shear stress on endothelial cells modulates mechanical tension across VE-cadherin and PECAM-1. Curr. Biol. 2013, 23, 1024-1030. [CrossRef] [PubMed]

51. Hove, J.R.; Köster, R.W.; Forouhar, A.S.; Acevedo-Bolton, G.; Fraser, S.E.; Gharib, M. Intracardiac fluid forces are an essential epigenetic factor for embryonic cardiogenesis. Nature 2003, 421, 172-177. [CrossRef] [PubMed]

52. Frost, H.M. Wolff's Law and bone's structural adaptations to mechanical usage: An overview for clinicians. Angle Orthod 1994, 64, 175-188. [PubMed]

53. Burger, E.H.; Klein-Nulend, J. Mechanotransduction in bone-Role of the lacuno-canalicular network. FASEB J. 1999, 13, S101-S112. [PubMed] 
54. Hoffman, B.D.; Grashoff, C.; Schwartz, M.A. Dynamic molecular processes mediate cellular mechanotransduction. Nature 2011, 475, 316-323. [CrossRef] [PubMed]

55. Polacheck, W.J.; Chen, C.S. Measuring cell-generated forces: A guide to the available tools. Nat. Methods 2016, 13, 415-423. [CrossRef] [PubMed]

56. Chrétien, M.L.; Zhang, M.; Jackson, M.R.; Kapus, A.; Langille, B.L. Mechanotransduction by endothelial cells is locally generated, direction-dependent, and ligand-specific. J. Cell. Physiol. 2010, 224, 352-361. [CrossRef] [PubMed]

57. Griffith, L.G.; Swartz, M.A. Capturing complex 3D tissue physiology in vitro. Nat. Rev. Mol. Cell Biol. 2006, 7, 211-224. [CrossRef] [PubMed]

58. Koch, T.M.; Münster, S.; Bonakdar, N.; Butler, J.P.; Fabry, B. 3D Traction forces in cancer cell invasion. PLoS ONE 2012, 7, e33476. [CrossRef] [PubMed]

59. Legant, W.R.; Miller, J.S.; Blakely, B.L.; Cohen, D.M.; Genin, G.M.; Chen, C.S. Measurement of mechanical tractions exerted by cells in three-dimensional matrices. Nat. Methods 2010, 7, 969-971. [CrossRef] [PubMed]

60. Hall, M.S.; Long, R.; Feng, X.; Huang, Y.; Hui, C.-Y.; Wu, M. Toward single cell traction microscopy within 3D collagen matrices. Exp. Cell Res. 2013, 319, 2396-2408. [CrossRef] [PubMed]

61. Chen, J.; Irianto, J.; Inamdar, S.; Pravincumar, P.; Lee, D.A.; Bader, D.L.; Knight, M.M. Cell mechanics, structure, and function are regulated by the stiffness of the three-dimensional microenvironment. Biophys. J. 2012, 103, 1188-1197. [CrossRef] [PubMed]

62. Li, Y.; Huang, G.; Li, M.; Wang, L.; Elson, E.L.; Lu, T.J.; Xu, F. An approach to quantifying 3D responses of cells to extreme strain. Sci. Rep. 2016, 6, 19550. [CrossRef] [PubMed]

63. Wang, N.; Tolić-Nørrelykke, I.M.; Chen, J.; Mijailovich, S.M.; Butler, J.P.; Fredberg, J.J.; Stamenović, D. Cell prestress. I. Stiffness and prestress are closely associated in adherent contractile cells. Am. J. Physiol. Cell Physiol. 2002, 282, C606-C616. [CrossRef] [PubMed]

64. Wozniak, M.A.; Chen, C.S. Mechanotransduction in development: A growing role for contractility. Nat. Rev. Mol. Cell Biol. 2009, 10, 34-43. [CrossRef] [PubMed]

65. Chowdhury, F.; Na, S.; Li, D.; Poh, Y.-C.; Tanaka, T.S.; Wang, F.; Wang, N. Material properties of the cell dictate stress-induced spreading and differentiation in embryonic stem cells. Nat. Mater. 2010, 9, 82-88. [CrossRef] [PubMed]

66. Kanchanawong, P.; Shtengel, G.; Pasapera, A.M.; Ramko, E.B.; Davidson, M.W.; Hess, H.F.; Waterman, C.M. Nanoscale architecture of integrin-based cell adhesions. Nature 2010, 468, 580-584. [CrossRef] [PubMed]

67. Zaidel-Bar, R.; Itzkovitz, S.; Ma'ayan, A.; Iyengar, R.; Geiger, B. Functional atlas of the integrin adhesome. Nat. Cell Biol. 2007, 9, 858-867. [CrossRef] [PubMed]

68. Butler, J.P.; Tolić-Nørrelykke, I.M.; Fabry, B.; Fredberg, J.J. Traction fields, moments, and strain energy that cells exert on their surroundings. Am. J. Physiol. Cell Physiol. 2002, 282, C595-C605. [CrossRef] [PubMed]

69. Tang, X.; Tofangchi, A.; Anand, S.V.; Saif, T.A. A Novel Cell Traction Force Microscopy to Study Multi-Cellular System. PLoS Comput. Biol. 2014, 10, e1003631. [CrossRef] [PubMed]

70. Zielinski, R.; Mihai, C.; Kniss, D.; Ghadiali, S.N. Finite element analysis of traction force microscopy: Influence of cell mechanics, adhesion, and morphology. J. Biomech. Eng. 2013, 135, 71009. [CrossRef] [PubMed]

71. Style, R.W.; Boltyanskiy, R.; German, G.K.; Hyland, C.; MacMinn, C.W.; Mertz, A.F.; Wilen, L.A.; Xu, Y.; Dufresne, E.R. Traction force microscopy in physics and biology. Soft Matter 2014, 10, 4047-4055. [CrossRef] [PubMed]

72. Takigawa, T.; Morino, Y.; Urayama, K.; Masuda, T. Poisson's ratio of polyacrylamide (PAAm) gels. Polym. Gels Netw. 1996, 4, 1-5. [CrossRef]

73. Boudou, T.; Ohayon, J.; Picart, C.; Tracqui, P. An extended relationship for the characterization of Young's modulus and Poisson's ratio of tunable polyacrylamide gels. Biorheology 2006, 43, 721-728. [PubMed]

74. Pritchard, R.H.; Lava, P.; Debruyne, D.; Terentjev, E.M. Precise determination of the Poisson ratio in soft materials with 2D digital image correlation. Soft Matter 2013, 9, 6037-6045. [CrossRef]

75. Maruthamuthu, V.; Sabass, B.; Schwarz, U.S.; Gardel, M.L. Cell-ECM traction force modulates endogenous tension at cell-cell contacts. Proc. Natl. Acad. Sci. USA 2011, 108, 4708-4713. [CrossRef] [PubMed]

76. Jasaitis, A.; Estevez, M.; Heysch, J.; Ladoux, B.; Dufour, S. E-cadherin-dependent stimulation of traction force at focal adhesions via the Src and PI3K signaling pathways. Biophys. J. 2012, 103, 175-184. [CrossRef] [PubMed] 
77. Plotnikov, S.V.; Sabass, B.; Schwarz, U.S.; Waterman, C.M. High-resolution traction force microscopy. Methods Cell Biol. 2014, 123, 367-394. [PubMed]

78. Tambe, D.T.; Corey Hardin, C.; Angelini, T.E.; Rajendran, K.; Park, C.Y.; Serra-Picamal, X.; Zhou, E.H.; Zaman, M.H.; Butle, J.P.; Weitz, D.A.; et al. Collective cell guidance by cooperative intercellular forces. Nat. Mater. 2011, 10, 469-475. [CrossRef] [PubMed]

79. Bergert, M.; Lendenmann, T.; Zündel, M.; Ehret, A.E.; Panozzo, D.; Richner, P.; Kim, D.K.; Kress, S.J.P.; Norris, D.J.; Sorkine-Hornung, O.; et al. Confocal reference free traction force microscopy. Nat. Commun. 2016, 7, 12814. [PubMed]

80. Soon, C.F.; Youseffi, M.; Berends, R.F.; Blagden, N.; Denyer, M.C.T. Development of a novel liquid crystal based cell traction force transducer system. Biosens. Bioelectron. 2013, 39, 14-20. [CrossRef] [PubMed]

81. Schoen, I.; Hu, W.; Klotzsch, E.; Vogel, V. Probing cellular traction forces by micropillar arrays: Contribution of substrate warping to pillar deflection. Nano Lett. 2010, 10, 1823-1830. [CrossRef] [PubMed]

82. Du Roure, O.; Saez, A.; Buguin, A.; Austin, R.H.; Chavrier, P.; Silberzan, P.; Ladoux, B. Force mapping in epithelial cell migration. Proc. Natl. Acad. Sci. USA 2005, 102, 2390-2395. [CrossRef] [PubMed]

83. Chen, J.; Li, H.; SundarRaj, N.; Wang, J.H.-C. Alpha-smooth muscle actin expression enhances cell traction force. Cell Motil. Cytoskelet. 2007, 64, 248-257. [CrossRef] [PubMed]

84. Morin, T.R.; Ghassem-Zadeh, S.A.; Lee, J. Traction force microscopy in rapidly moving cells reveals separate roles for ROCK and MLCK in the mechanics of retraction. Exp. Cell Res. 2014, 326, 280-294. [CrossRef] [PubMed]

85. Munevar, S.; Wang, Y.; Dembo, M. Traction force microscopy of migrating normal and H-ras transformed 3T3 fibroblasts. Biophys. J. 2001, 80, 1744-1757. [CrossRef]

86. Li, B.; Li, F.; Puskar, K.M.; Wang, J.H.-C. Spatial patterning of cell proliferation and differentiation depends on mechanical stress magnitude. J. Biomech. 2009, 42, 1622-1627. [CrossRef] [PubMed]

87. Huebsch, N.; Arany, P.R.; Mao, A.S.; Shvartsman, D.; Ali, O.A.; Bencherif, S.A.; Rivera-Feliciano, J.; Mooney, D.J. Harnessing traction-mediated manipulation of the cell/matrix interface to control stem-cell fate. Nat. Mater. 2010, 9, 518-526. [CrossRef] [PubMed]

88. Mousavi, S.J.; Doweidar, M.H. Role of Mechanical Cues in Cell Differentiation and Proliferation: A 3D Numerical Model. PLoS ONE 2015, 10, e0124529. [CrossRef] [PubMed]

89. Fabry, B.; Maksym, G.N.; Butler, J.P.; Glogauer, M.; Navajas, D.; Fredberg, J.J. Scaling the Microrheology of Living Cells. Phys. Rev. Lett. 2001, 87, 148102. [CrossRef] [PubMed]

90. Stamenović, D.; Rosenblatt, N.; Montoya-Zavala, M.; Matthews, B.D.; Hu, S.; Suki, B.; Wang, N.; Ingber, D.E. Rheological behavior of living cells is timescale-dependent. Biophys. J. 2007, 93, L39-L41. [CrossRef] [PubMed]

91. Trepat, X.; Deng, L.; An, S.S.; Navajas, D.; Tschumperlin, D.J.; Gerthoffer, W.T.; Butler, J.P.; Fredberg, J.J. Universal physical responses to stretch in the living cell. Nature 2007, 447, 592-595. [CrossRef] [PubMed]

92. Na, S.; Collin, O.; Chowdhury, F.; Tay, B.; Ouyang, M.; Wang, Y.; Wang, N. Rapid signal transduction in living cells is a unique feature of mechanotransduction. Proc. Natl. Acad. Sci. USA 2008, 105, 6626-6631. [CrossRef] [PubMed]

93. Chowdhury, F.; Na, S.; Collin, O.; Tay, B.; Li, F.; Tanaka, T.; Leckband, D.E.; Wang, N. Is cell rheology governed by nonequilibrium-to-equilibrium transition of noncovalent bonds? Biophys. J. 2008, 95, 5719-5727. [CrossRef] [PubMed]

94. Overby, D.R.; Matthews, B.D.; Alsberg, E.; Ingber, D.E. Novel dynamic rheological behavior of individual focal adhesions measured within single cells using electromagnetic pulling cytometry. Acta Biomater. 2005, 1, 295-303. [CrossRef] [PubMed]

95. Matthews, B.D.; Overby, D.R.; Alenghat, F.J.; Karavitis, J.; Numaguchi, Y.; Allen, P.G.; Ingber, D.E. Mechanical properties of individual focal adhesions probed with a magnetic microneedle. Biochem. Biophys. Res. Commun. 2004, 313, 758-764. [CrossRef] [PubMed]

96. Matthews, B.D.; Overby, D.R.; Mannix, R.; Ingber, D.E. Cellular adaptation to mechanical stress: Role of integrins, Rho, cytoskeletal tension and mechanosensitive ion channels. J. Cell Sci. 2006, 119, 508-518. [CrossRef] [PubMed]

97. Matthews, B.D.; Thodeti, C.K.; Tytell, J.D.; Mammoto, A.; Overby, D.R.; Ingber, D.E. Ultra-rapid activation of TRPV4 ion channels by mechanical forces applied to cell surface beta1 integrins. Integr. Biol. 2010, 2, 435-442. [CrossRef] [PubMed] 
98. Wang, Y.; Discher, D.E. Cell Mechanics; Elsevier Academic Press: San Diego, CA, USA, 2007.

99. Matthews, B.D.; LaVan, D.A.; Overby, D.R.; Karavitis, J.; Ingber, D.E. Electromagnetic needles with submicron pole tip radii for nanomanipulation of biomolecules and living cells. Appl. Phys. Lett. 2004, 85, 2968-2970. [CrossRef]

100. Barry, A.K.; Tabdili, H.; Muhamed, I.; Wu, J.; Shashikanth, N.; Gomez, G.A.; Yap, A.S.; Gottardi, C.J.; de Rooij, J.; Wang, N.; et al. $\alpha$-Catenin cytomechanics: Role in cadherin-dependent adhesion and mechanotransduction. J. Cell Sci. 2014, 127, 1779-1791. [CrossRef] [PubMed]

101. Ashkin, A.; Dziedzic, J.M.; Bjorkholm, J.E.; Chu, S. Observation of a single-beam gradient force optical trap for dielectric particles. Opt. Lett. 1986, 11, 288-290. [CrossRef] [PubMed]

102. Ashkin, A. Acceleration and Trapping of Particles by Radiation Pressure. Phys. Rev. Lett. 1970, 24, 156-159. [CrossRef]

103. Swank, D.M.; Bartoo, M.L.; Knowles, A.F.; Iliffe, C.; Bernstein, S.I.; Molloy, J.E.; Sparrow, J.C. Alternative Exon-encoded Regions of Drosophila Myosin Heavy Chain Modulate ATPase Rates and Actin Sliding Velocity. J. Biol. Chem. 2001, 276, 15117-15124. [CrossRef] [PubMed]

104. Yildiz, A.; Park, H.; Safer, D.; Yang, Z.; Chen, L.-Q.; Selvin, P.R.; Sweeney, H.L. Myosin VI steps via a hand-over-hand mechanism with its lever arm undergoing fluctuations when attached to actin. J. Biol. Chem. 2004, 279, 37223-37226. [CrossRef] [PubMed]

105. Yildiz, A.; Forkey, J.N.; McKinney, S.A.; Ha, T.; Goldman, Y.E.; Selvin, P.R. Myosin V walks hand-over-hand: Single fluorophore imaging with 1.5-nm localization. Science 2003, 300, 2061-2065. [CrossRef] [PubMed]

106. Asbury, C.L.; Fehr, A.N.; Block, S.M. Kinesin Moves by an Asymmetric Hand-Over-Hand Mechanism. Science 2003, 302, 2130-2134. [CrossRef] [PubMed]

107. Block, S.M.; Asbury, C.L.; Shaevitz, J.W.; Lang, M.J. Probing the kinesin reaction cycle with a 2D optical force clamp. Proc. Natl. Acad. Sci. USA 2003, 100, 2351-2356. [CrossRef] [PubMed]

108. Mallik, R.; Carter, B.C.; Lex, S.A.; King, S.J.; Gross, S.P. Cytoplasmic dynein functions as a gear in response to load. Nature 2004, 427, 649-652. [CrossRef] [PubMed]

109. Reck-Peterson, S.L.; Yildiz, A.; Carter, A.P.; Gennerich, A.; Zhang, N.; Vale, R.D. Single-molecule analysis of dynein processivity and stepping behavior. Cell 2006, 126, 335-348. [CrossRef] [PubMed]

110. Gennerich, A.; Carter, A.P.; Reck-Peterson, S.L.; Vale, R.D. Force-induced bidirectional stepping of cytoplasmic dynein. Cell 2007, 131, 952-965. [CrossRef] [PubMed]

111. Berry, R.M.; Berg, H.C. Absence of a barrier to backwards rotation of the bacterial flagellar motor demonstrated with optical tweezers. Biophysics 1997, 94, 14433-14437. [CrossRef]

112. Block, S.M.; Blair, D.F.; Berg, H.C. Compliance of bacterial flagella measured with optical tweezers. Nature 1989, 338, 514-518. [CrossRef] [PubMed]

113. Yin, H.; Wang, M.D.; Svoboda, K.; Landick, R.; Block, S.M.; Gelles, J. Transcription against an applied force. Science 1995, 270, 1653-1657. [CrossRef] [PubMed]

114. Wuite, G.J.L.; Smith, S.B.; Young, M.; Keller, D.; Bustamante, C. Single-molecule studies of the effect of template tension on T7 DNA polymerase activity. Nature 2000, 404, 103-106. [PubMed]

115. Liphardt, J.; Onoa, B.; Smith, S.B.; Tinoco, I.; Bustamante, C. Reversible Unfolding of Single RNA Molecules by Mechanical Force. Science 2001, 292, 733-737. [CrossRef] [PubMed]

116. Allemand, J.-F.; Bensimon, D.; Croquette, V. Stretching DNA and RNA to probe their interactions with proteins. Curr. Opin. Struct. Biol. 2003, 13, 266-274. [CrossRef]

117. Abbondanzieri, E.A.; Greenleaf, W.J.; Shaevitz, J.W.; Landick, R.; Block, S.M. Direct observation of base-pair stepping by RNA polymerase. Nature 2005, 438, 460-465. [CrossRef] [PubMed]

118. Myong, S.; Bruno, M.M.; Pyle, A.M.; Ha, T. Spring-Loaded Mechanism of DNA Unwinding by Hepatitis C Virus NS3 Helicase. Science 2007, 317, 513-516. [CrossRef] [PubMed]

119. Lee, K.S.; Balci, H.; Jia, H.; Lohman, T.M.; Ha, T. Direct imaging of single UvrD helicase dynamics on long single-stranded DNA. Nat. Commun. 2013, 4, 1878. [CrossRef] [PubMed]

120. Ngo, T.T.M.; Zhang, Q.; Zhou, R.; Yodh, J.G.; Ha, T. Asymmetric Unwrapping of Nucleosomes under Tension Directed by DNA Local Flexibility. Cell 2015, 160, 1135-1144. [CrossRef] [PubMed]

121. Choquet, D.; Felsenfeld, D.P.; Sheetz, M.P. Extracellular matrix rigidity causes strengthening of integrin-cytoskeleton linkages. Cell 1997, 88, 39-48. [CrossRef] 
122. Raucher, D.; Stauffer, T.; Chen, W.; Shen, K.; Guo, S.; York, J.D.; Sheetz, M.P.; Meyer, T. Phosphatidylinositol 4,5-bisphosphate functions as a second messenger that regulates cytoskeleton-plasma membrane adhesion. Cell 2000, 100, 221-228. [CrossRef]

123. Suresh, S.; Spatz, J.; Mills, J.P.; Micoulet, A.; Dao, M.; Lim, C.T.; Beil, M.; Seufferlein, T. Connections between single-cell biomechanics and human disease states: Gastrointestinal cancer and malaria. Acta Biomater. 2005, 1, 15-30. [CrossRef] [PubMed]

124. Grashoff, C.; Hoffman, B.D.; Brenner, M.D.; Zhou, R.; Parsons, M.; Yang, M.T.; McLean, M.A.; Sligar, S.G.; Chen, C.S.; Ha, T.; et al. Measuring mechanical tension across vinculin reveals regulation of focal adhesion dynamics. Nature 2010, 466, 263-266. [CrossRef] [PubMed]

125. Blakely, B.L.; Dumelin, C.E.; Trappmann, B.; McGregor, L.M.; Choi, C.K.; Anthony, P.C.; Duesterberg, V.K.; Baker, B.M.; Block, S.M.; Liu, D.R.; et al. A DNA-based molecular probe for optically reporting cellular traction forces. Nat. Methods 2014, 11, 1229-1232. [CrossRef] [PubMed]

126. Chowdhury, F.; Li, I.T.S.; Ngo, T.T.M.; Leslie, B.J.; Kim, B.C.; Sokoloski, J.E.; Weiland, E.; Wang, X.; Chemla, Y.R.; Lohman, T.M.; et al. Defining Single Molecular Forces Required for Notch Activation Using Nano Yoyo. Nano Lett. 2016, 16, 3892-3897. [CrossRef] [PubMed]

127. Chu, S. Nobel Lecture: The manipulation of neutral particles. Rev. Mod. Phys. 1998, 70, 685-706. [CrossRef]

128. Zhang, H.; Liu, K.-K. Optical tweezers for single cells. J. R. Soc. Interface 2008, 5, 671-690. [CrossRef] [PubMed]

129. Ramser, K.; Hanstorp, D. Optical manipulation for single-cell studies. J. Biophotonics 2010, 3, $187-206$. [CrossRef] [PubMed]

130. Neuman, K.C.; Nagy, A. Single-molecule force spectroscopy: Optical tweezers, magnetic tweezers and atomic force microscopy. Nat. Methods 2008, 5, 491-505. [CrossRef] [PubMed]

131. Moffitt, J.R.; Chemla, Y.R.; Izhaky, D.; Bustamante, C. Differential detection of dual traps improves the spatial resolution of optical tweezers. Proc. Natl. Acad. Sci. USA 2006, 103, 9006-9011. [CrossRef] [PubMed]

132. Gaczynska, M.; Osmulski, P.A. AFM of biological complexes: What can we learn? Curr. Opin. Colloid Interface Sci. 2008, 13, 351-367. [CrossRef] [PubMed]

133. Haase, K.; Pelling, A.E. Investigating cell mechanics with atomic force microscopy. J. R. Soc. Interface 2015, 12, 20140970. [CrossRef] [PubMed]

134. Mathur, A.B.; Truskey, G.A.; Reichert, W.M. Atomic force and total internal reflection fluorescence microscopy for the study of force transmission in endothelial cells. Biophys. J. 2000, 78, 1725-1735. [CrossRef]

135. Akhremitchev, B.B.; Walker, G.C. Finite sample thickness effects on elasticity determination using atomic force microscopy. Langmuir 1999, 15, 5630-5634. [CrossRef]

136. Maki, K.; Han, S.-W.; Hirano, Y.; Yonemura, S.; Hakoshima, T.; Adachi, T. Mechano-adaptive sensory mechanism of $\alpha$-catenin under tension. Sci. Rep. 2016, 6, 24878. [CrossRef] [PubMed]

137. Raman, A.; Trigueros, S.; Cartagena, A.; Stevenson, A.P.Z.; Susilo, M.; Nauman, E.; Contera, S.A. Mapping nanomechanical properties of live cells using multi-harmonic atomic force microscopy. Nat. Nanotechnol. 2011, 6, 809-814. [CrossRef] [PubMed]

138. Sivasankar, S.; Brieher, W.; Lavrik, N.; Gumbiner, B.; Leckband, D. Direct molecular force measurements of multiple adhesive interactions between cadherin ectodomains. Proc. Natl. Acad. Sci. USA 1999, 96, 11820-11824. [CrossRef] [PubMed]

139. Shi, Q.; Chien, Y.-H.; Leckband, D. Biophysical properties of cadherin bonds do not predict cell sorting. J. Biol. Chem. 2008, 283, 28454-28463. [CrossRef] [PubMed]

140. Dragovich, M.A.; Chester, D.; Fu, B.M.; Wu, C.; Xu, Y.; Goligorsky, M.S.; Zhang, X.F. Mechanotransduction of the endothelial glycocalyx mediates nitric oxide production through activation of TRP channels. Am. J. Physiol. Cell Physiol. 2016, 311, C846-C853. [CrossRef] [PubMed]

141. Liou, J.W.; Mulet, X.; Klug, D.R. Absolute Measurement of Phosphorylation Levels in a Biological Membrane Using Atomic Force Microscopy: The Creation of Phosphorylation Maps. Biochemisty 2002, 41, 8535-8539. [CrossRef]

142. Philippsen, A.; Im, W.; Engel, A.; Schirmer, T.; Roux, B.; Müller, D.J. Imaging the Electrostatic Potential of Transmembrane Channels: Atomic Probe Microscopy of OmpF Porin. Biophys. J. 2002, 82, 1667-1676. [CrossRef] 
143. Tzima, E.; del Pozo, M.A.; Shattil, S.J.; Chien, S.; Schwartz, M.A. Activation of integrins in endothelial cells by fluid shear stress mediates Rho-dependent cytoskeletal alignment. EMBO J. 2001, 20, 4639-4647. [CrossRef] [PubMed]

144. Tzima, E.; Irani-Tehrani, M.; Kiosses, W.B.; Dejana, E.; Schultz, D.A.; Engelhardt, B.; Cao, G.; DeLisser, H.; Schwartz, M.A. A mechanosensory complex that mediates the endothelial cell response to fluid shear stress. Nature 2005, 437, 426-431. [CrossRef] [PubMed]

145. Fuhrmann, A.; Engler, A.J. Acute shear stress direction dictates adherent cell remodeling and verifies shear profile of spinning disk assays. Phys. Biol. 2015, 12, 16011. [CrossRef] [PubMed]

146. Bacabac, R.G.; Smit, T.H.; Cowin, S.C.; Van Loon, J.J.W.A.; Nieuwstadt, F.T.M.; Heethaar, R.; Klein-Nulend, J. Dynamic shear stress in parallel-plate flow chambers. J. Biomech. 2005, 38, 159-167. [CrossRef] [PubMed]

147. Lane, W.O.; Jantzen, A.E.; Carlon, T.A.; Jamiolkowski, R.M.; Grenet, J.E.; Ley, M.M.; Haseltine, J.M.; Galinat, L.J.; Lin, F.H.; Allen, J.D.; et al. Parallel-plate flow chamber and continuous flow circuit to evaluate endothelial progenitor cells under laminar flow shear stress. J. Vis. Exp. 2012, 59. [CrossRef] [PubMed]

148. Steward, R.; Tambe, D.; Hardin, C.C.; Krishnan, R.; Fredberg, J.J.; Fredberg, J.J. Fluid shear, intercellular stress, and endothelial cell alignment. Am. J. Physiol. Cell Physiol. 2015, 308, C657-C664. [CrossRef] [PubMed]

149. Polacheck, W.J.; Li, R.; Uzel, S.G.M.; Kamm, R.D. Microfluidic platforms for mechanobiology. Lab Chip 2013, 13, 2252-2267. [CrossRef] [PubMed]

150. Mak, M.; Reinhart-King, C.A.; Erickson, D. Elucidating mechanical transition effects of invading cancer cells with a subnucleus-scaled microfluidic serial dimensional modulation device. Lab Chip 2013, 13, 340-348. [CrossRef] [PubMed]

151. Vickerman, V.; Blundo, J.; Chung, S.; Kamm, R. Design, fabrication and implementation of a novel multi-parameter control microfluidic platform for three-dimensional cell culture and real-time imaging. Lab Chip 2008, 8, 1468-1477. [CrossRef] [PubMed]

152. Kim, H.J.; Huh, D.; Hamilton, G.; Ingber, D.E. Human gut-on-a-chip inhabited by microbial flora that experiences intestinal peristalsis-like motions and flow. Lab Chip 2012, 12, 2165-2174. [CrossRef] [PubMed]

153. Malboubi, M.; Jayo, A.; Parsons, M.; Charras, G. An open access microfluidic device for the study of the physical limits of cancer cell deformation during migration in confined environments. Microelectron. Eng. 2015, 144, 42-45. [CrossRef] [PubMed]

154. Song, J.W.; Gu, W.; Futai, N.; Warner, K.A.; Nor, J.E.; Takayama, S. Computer-controlled microcirculatory support system for endothelial cell culture and shearing. Anal. Chem. 2005, 77, 3993-3999. [CrossRef] [PubMed]

155. Hirata, H.; Tatsumi, H.; Sokabe, M. Mechanical forces facilitate actin polymerization at focal adhesions in a zyxin-dependent manner. J. Cell Sci. 2008, 121, 2795-2804. [CrossRef] [PubMed]

156. Hoffman, L.M.; Jensen, C.C.; Chaturvedi, A.; Yoshigi, M.; Beckerle, M.C. Stretch-induced actin remodeling requires targeting of zyxin to stress fibers and recruitment of actin regulators. Mol. Biol. Cell 2012, 23, 1846-1859. [CrossRef] [PubMed]

157. Dugan, J.M.; Cartmell, S.H.; Gough, J.E. Uniaxial cyclic strain of human adipose-derived mesenchymal stem cells and C2C12 myoblasts in coculture. J. Tissue Eng. 2014, 5, 2041731414530138. [CrossRef] [PubMed]

158. Upton, M.L.; Hennerbichler, A.; Fermor, B.; Guilak, F.; Weinberg, J.B.; Setton, L.A. Biaxial strain effects on cells from the inner and outer regions of the meniscus. Connect. Tissue Res. 2006, 47, 207-214. [CrossRef] [PubMed]

159. Ursekar, C.P.; Teo, S.-K.; Hirata, H.; Harada, I.; Chiam, K.-H.; Sawada, Y. Design and construction of an equibiaxial cell stretching system that is improved for biochemical analysis. PLoS ONE 2014, 9, e90665. [CrossRef] [PubMed]

160. Sotoudeh, M.; Jalali, S.; Usami, S.; Shyy, J.Y.; Chien, S. A strain device imposing dynamic and uniform equi-biaxial strain to cultured cells. Ann. Biomed. Eng. 1998, 26, 181-189. [CrossRef] [PubMed]

161. Lodish, H.; Berk, A.; Matsudaira, P.; Kaiser, C.A.; Krieger, M.; Scott, M.P.; Bretscher, A.; Ploegh, H. Molecular Cell Biology; W.H. Freeman and Company: New York, NY, USA, 2008.

162. Collins, C.; Guilluy, C.; Welch, C.; O’Brien, E.T.; Hahn, K.; Superfine, R.; Burridge, K.; Tzima, E. Localized tensional forces on PECAM-1 elicit a global mechanotransduction response via the integrin-RhoA pathway. Curr. Biol. 2012, 22, 2087-2094. [CrossRef] [PubMed] 
163. Seong, J.; Tajik, A.; Sun, J.; Guan, J.; Humphries, M.J.; Craig, S.E.; Shekaran, A.; García, A.J.; Lu, S.; Lin, M.Z.; et al. Distinct biophysical mechanisms of focal adhesion kinase mechanoactivation by different extracellular matrix proteins. Proc. Natl. Acad. Sci. USA 2013, 110, 19372-19377. [CrossRef] [PubMed]

164. Leckband, D.; Shi, Q.; Langer, M.; Tabdili, H.; Wang, N.; Poh, Y.-C. Cadherin-dependent mechanotransduction depends on ligand identity but not affinity. J. Cell Sci. 2012, 125, 4362-4371.

165. Li, J.; Han, D.; Zhao, Y.-P. Kinetic behaviour of the cells touching substrate: The interfacial stiffness guides cell spreading. Sci. Rep. 2014, 4, 3910. [CrossRef] [PubMed]

166. Chen, W.; Lou, J.; Evans, E.A.; Zhu, C. Observing force-regulated conformational changes and ligand dissociation from a single integrin on cells. J. Cell Biol. 2012, 199, 497-512. [CrossRef] [PubMed]

167. Rangarajan, E.S.; Izard, T. The cytoskeletal protein $\alpha$-catenin unfurls upon binding to vinculin. J. Biol. Chem. 2012, 287, 18492-18499. [CrossRef] [PubMed]

168. Bakolitsa, C.; Cohen, D.M.; Bankston, L.A.; Bobkov, A.A.; Cadwell, G.W.; Jennings, L.; Critchley, D.R.; Craig, S.W.; Liddington, R.C. Structural basis for vinculin activation at sites of cell adhesion. Nature 2004, 430, 583-586. [CrossRef] [PubMed]

169. Chen, H.; Choudhury, D.M.; Craig, S.W. Coincidence of actin filaments and talin is required to activate vinculin. J. Biol. Chem. 2006, 281, 40389-40398. [CrossRef] [PubMed]

170. Choi, H.-J.; Pokutta, S.; Cadwell, G.W.; Bobkov, A.A.; Bankston, L.A.; Liddington, R.C.; Weis, W.I. $\alpha$ E-catenin is an autoinhibited molecule that coactivates vinculin. Proc. Natl. Acad. Sci. USA 2012, 109, 8576-8581. [CrossRef] [PubMed]

171. Peng, X.; Maiers, J.L.; Choudhury, D.; Craig, S.W.; DeMali, K.A. $\alpha$-Catenin uses a novel mechanism to activate vinculin. J. Biol. Chem. 2012, 287, 7728-7737. [CrossRef] [PubMed]

172. Campbell, I.D.; Humphries, M.J. Integrin structure, activation, and interactions. Cold Spring Harb. Perspect. Biol. 2011, 3, 1-14. [CrossRef] [PubMed]

173. Michael, K.E.; Dumbauld, D.W.; Burns, K.L.; Hanks, S.K.; García, A.J. Focal adhesion kinase modulates cell adhesion strengthening via integrin activation. Mol. Biol. Cell 2009, 20, 2508-2519. [CrossRef] [PubMed]

174. Nishitani, W.S.; Saif, T.A.; Wang, Y. Calcium signaling in live cells on elastic gels under mechanical vibration at subcellular levels. PLoS ONE 2011, 6, e26181. [CrossRef] [PubMed]

175. Brown, M.C.; Cary, L.A.; Jamieson, J.S.; Cooper, J.A.; Turner, C.E. Src and FAK kinases cooperate to phosphorylate paxillin kinase linker, stimulate its focal adhesion localization, and regulate cell spreading and protrusiveness. Mol. Biol. Cell 2005, 16, 4316-4328. [CrossRef] [PubMed]

176. Wheelock, M.J.; Johnson, K.R. Cadherin-mediated cellular signaling. Curr. Opin. Cell Biol. 2003, 15, 509-514. [CrossRef]

177. Leckband, D.E.; de Rooij, J. Cadherin adhesion and mechanotransduction. Annu. Rev. Cell Dev. Biol. 2014, 30, 291-315. [CrossRef] [PubMed]

178. Johnson, A.W.; Harley, B.A.C. Mechanobiology of Cell-Cell and Cell-Matrix Interactions; Springer: Berlin, Germnay, 2011; pp. 11-23.

179. Takada, Y.; Ye, X.; Simon, S. The integrins. Genome Biol. Genome Biol. 2007, 8, 215. [CrossRef] [PubMed]

180. Orgovan, N.; Peter, B.; Bősze, S.; Ramsden, J.J.; Szabó, B.; Horvath, R. Dependence of cancer cell adhesion kinetics on integrin ligand surface density measured by a high-throughput label-free resonant waveguide grating biosensor. Sci. Rep. 2014, 4, 1216-1219. [CrossRef] [PubMed]

181. Ruoslahti, E. RGD and other recognition sequences for integrins. Annu. Rev. Cell Dev. Biol. 1996, 12, 697-715. [CrossRef] [PubMed]

182. Barczyk, M.; Carracedo, S.; Gullberg, D. Integrins. Cell Tissue Res. 2010, 339, 269-280. [CrossRef] [PubMed]

183. Askari, J.A.; Buckley, P.A.; Mould, A.P.; Humphries, M.J. Linking integrin conformation to function. J. Cell Sci. 2008, 122, 165-170. [CrossRef] [PubMed]

184. Mecham, R.P. Overview of Extracellular Matrix. In Current Protocols in Cell Biology; Hoboken, N.J., Ed.; John Wiley \& Sons, Inc.: New York, NY, USA, 2012.

185. Villard, V.; Kalyuzhniy, O.; Riccio, O.; Potekhin, S.; Melnik, T.N.; Kajava, A.V.; Rüegg, C.; Corradin, G. Synthetic RGD-containing alpha-helical coiled coil peptides promote integrin-dependent cell adhesion. J. Pept. Sci. 2006, 12, 206-212. [CrossRef] [PubMed]

186. Bellis, S.L. Advantages of RGD peptides for directing cell association with biomaterials. Biomaterials 2011, 32, 4205-4210. [CrossRef] [PubMed] 
187. Borghi, N.; Lowndes, M.; Maruthamuthu, V.; Gardel, M.L.; Nelson, W.J. Regulation of cell motile behavior by crosstalk between cadherin- and integrin-mediated adhesions. Proc. Natl. Acad. Sci. USA 2010, 107, 13324-13329. [CrossRef] [PubMed]

188. Chigaev, A.; Buranda, T.; Dwyer, D.C.; Prossnitz, E.R.; Sklar, L.A. FRET Detection of Cellular $\alpha 4$-Integrin Conformational Activation. Biophys. J. 2003, 85, 3951-3962. [CrossRef]

189. Ye, F.; Liu, J.; Winkler, H.; Taylor, K.A. Integrin $\alpha \operatorname{Ilb} \beta 3$ in a Membrane Environment Remains the Same Height after Mn2+ Activation when Observed by Cryoelectron Tomography. J. Mol. Biol. 2008, 378, 976-986. [CrossRef] [PubMed]

190. Takagi, J.; Petre, B.M.; Walz, T.; Springer, T.A. Global Conformational Rearrangements in Integrin Extracellular Domains in Outside-In and Inside-Out Signaling. Cell 2002, 110, 599-611. [CrossRef]

191. Gallant, N.D.; Michael, K.E.; García, A.J. Cell adhesion strengthening: Contributions of adhesive area, integrin binding, and focal adhesion assembly. Mol. Biol. Cell 2005, 16, 4329-4340. [CrossRef] [PubMed]

192. Zaidel-Bar, R.; Cohen, M.; Addadi, L.; Geiger, B. Hierarchical assembly of cell-matrix adhesion complexes. Biochem. Soc. Trans. 2004, 32, 416-420. [CrossRef] [PubMed]

193. Geiger, B.; Spatz, J.P.; Bershadsky, A.D. Environmental sensing through focal adhesions. Nat. Rev. Mol. Cell Biol. 2009, 10, 21-33. [CrossRef] [PubMed]

194. Zimerman, B.; Volberg, T.; Geiger, B. Early molecular events in the assembly of the focal adhesion-stress fiber complex during fibroblast spreading. Cell Motil. Cytoskelet. 2004, 58, 143-159. [CrossRef] [PubMed]

195. De Rooij, J.; Kerstens, A.; Danuser, G.; Schwartz, M.A.; Waterman-Storer, C.M. Integrin-dependent actomyosin contraction regulates epithelial cell scattering. J. Cell Biol. 2005, 171, 153-164. [CrossRef] [PubMed]

196. Danuser, G.; Waterman-Storer, C.M. Quantitative fluorescent speckle microscopy of cytoskeleton dynamics. Annu. Rev. Biophys. Biomol. Struct. 2006, 35, 361-387. [CrossRef] [PubMed]

197. Choi, C.K.; Vicente-Manzanares, M.; Zareno, J.; Whitmore, L.A.; Mogilner, A.; Horwitz, A.R. Actin and alpha-actinin orchestrate the assembly and maturation of nascent adhesions in a myosin II motor-independent manner. Nat. Cell Biol. 2008, 10, 1039-1050. [CrossRef] [PubMed]

198. Birukova, A.A.; Fu, P.; Xing, J.; Yakubov, B.; Cokic, I.; Birukov, K.G. Mechanotransduction by GEF-H1 as a novel mechanism of ventilator-induced vascular endothelial permeability. Am. J. Physiol. Lung Cell. Mol. Physiol. 2010, 298, L837-L848. [CrossRef] [PubMed]

199. Totsukawa, G.; Yamakita, Y.; Yamashiro, S.; Hartshorne, D.J.; Sasaki, Y.; Matsumura, F. Distinct Roles of Rock (Rho-Kinase) and Mlck in Spatial Regulation of Mlc Phosphorylation for Assembly of Stress Fibers and Focal Adhesions in 3t3 Fibroblasts. J. Cell Biol. 2000, 150, 797-806. [CrossRef] [PubMed]

200. Kimura, K.; Ito, M.; Amano, M.; Chihara, K.; Fukata, Y.; Nakafuku, M.; Okawa, K.; Iwamatsu, A.; Kaibuchi, K. Regulation of myosin phosphatase by Rho and Rho-associated kinase (Rho-kinase). Science 1996, 273, 245-248. [CrossRef] [PubMed]

201. Wozniak, M.A.; Modzelewska, K.; Kwong, L.; Keely, P.J. Focal adhesion regulation of cell behavior. Biochim. Biophys. Acta Mol. Cell Res. 2004, 1692, 103-119. [CrossRef] [PubMed]

202. Oakes, P.W.; Beckham, Y.; Stricker, J.; Gardel, M.L. Tension is required but not sufficient for focal adhesion maturation without a stress fiber template. J. Cell Biol. 2012, 196, 363-374. [CrossRef] [PubMed]

203. Katoh, K. Role of stress fibers and focal adhesions as a mediator for mechano-signal transduction in endothelial cells in situ. Vasc. Health Risk Manag. 2008, 4, 1273-1282. [CrossRef] [PubMed]

204. Calderwood, D.A.; Campbell, I.D.; Critchley, D.R. Talins and kindlins: Partners in integrin-mediated adhesion. Nat. Rev. Mol. Cell Biol. 2013, 14, 503-517. [CrossRef] [PubMed]

205. Dumbauld, D.W.; Lee, T.T.; Singh, A.; Scrimgeour, J.; Gersbach, C.A.; Zamir, E.A.; Fu, J.; Chen, C.S.; Curtis, J.E.; Craig, S.W.; et al. How vinculin regulates force transmission. Proc. Natl. Acad. Sci. USA 2013, 110, 9788-9793. [CrossRef] [PubMed]

206. Wang, X.; Sun, J.; Xu, Q.; Chowdhury, F.; Roein-Peikar, M.; Wang, Y.; Ha, T. Integrin Molecular Tension within Motile Focal Adhesions. Biophys. J. 2015, 109, 2259-2267. [CrossRef] [PubMed]

207. Plotnikov S, V.; Pasapera, A.M.; Sabass, B.; Waterman, C.M. Force fluctuations within focal adhesions mediate ECM-rigidity sensing to guide directed cell migration. Cell 2012, 151, 1513-1527. [CrossRef] [PubMed]

208. Wang, Y.; Wang, X. Integrins outside focal adhesions transmit tensions during stable cell adhesion. Sci. Rep. 2016, 6, 36959. [CrossRef] [PubMed] 
209. Harburger, D.S.; Calderwood, D.A. Integrin signalling at a glance. J. Cell Sci. 2009, 122, 159-163. [CrossRef] [PubMed]

210. Mitra, S.K.; Hanson, D.A.; Schlaepfer, D.D. Focal adhesion kinase: In command and control of cell motility. Nat. Rev. Mol. Cell Biol. 2005, 6, 56-68. [CrossRef] [PubMed]

211. Liu, S.; Calderwood, D.A.; Ginsberg, M.H. Integrin cytoplasmic domain-binding proteins. J. Cell Sci. 2000, 113, 3563-3571. [PubMed]

212. Herzog, F.A.; Vogel, V. Multiple steps to activate FAK's kinase domain: Adaptation to confined environments? Biophys. J. 2013, 104, 2521-2529. [CrossRef] [PubMed]

213. Lietha, D.; Cai, X.; Ceccarelli, D.F.J.; Li, Y.; Schaller, M.D.; Eck, M.J. Structural basis for the autoinhibition of focal adhesion kinase. Cell 2007, 129, 1177-1187. [CrossRef] [PubMed]

214. Ouyang, M.; Sun, J.; Chien, S.; Wang, Y. Determination of hierarchical relationship of Src and Rac at subcellular locations with FRET biosensors. Proc. Natl. Acad. Sci. USA 2008, 105, 14353-14358. [CrossRef] [PubMed]

215. Seong, J.; Lu, S.; Wang, Y. Live Cell Imaging of Src/FAK Signaling by FRET. Cell. Mol. Bioeng. 2011, 2, 138-147. [CrossRef] [PubMed]

216. Chung, C.Y.; Lee, S.; Briscoe, C.; Ellsworth, C.; Firtel, R.A. Role of Rac in controlling the actin cytoskeleton and chemotaxis in motile cells. Proc. Natl. Acad. Sci. USA 2000, 97, 5225-5230. [CrossRef] [PubMed]

217. Liao, J.K.; Seto, M.; Noma, K. Rho kinase (ROCK) inhibitors. J. Cardiovasc. Pharmacol. 2007, 50, 17-24. [CrossRef] [PubMed]

218. Tapon, N.; Hall, A. Rho, Rac and Cdc42 GTPases regulate the organization of the actin cytoskeleton. Curr. Opin. Cell Biol. 1997, 9, 86-92. [CrossRef]

219. Spiering, D.; Hodgson, L. Dynamics of the rho-family small GTPases in actin regulation and motility. Cell Adhes. Migr. 2011, 5, 170-180. [CrossRef]

220. Lawrence, D.S.; Wang, Q. Seeing is believing: Peptide-based fluorescent sensors of protein tyrosine kinase activity. ChemBioChem 2007, 8, 373-378. [CrossRef] [PubMed]

221. Harvey, C.D.; Ehrhardt, A.G.; Cellurale, C.; Zhong, H.; Yasuda, R.; Davis, R.J.; Svoboda, K. A genetically encoded fluorescent sensor of ERK activity. Proc. Natl. Acad. Sci. USA 2008, 105, 19264-19269. [CrossRef] [PubMed]

222. González-Mariscal, L.; Betanzos, A.; Nava, P.; Jaramillo, B.E. Tight junction proteins. Prog. Biophys. Mol. Biol. 2003, 81, 1-44. [CrossRef]

223. Bazzoni, G.; Dejana, E. Endothelial cell-to-cell junctions: Molecular organization and role in vascular homeostasis. Physiol. Rev. 2004, 84, 869-901. [CrossRef] [PubMed]

224. Giepmans, B.N.G. Gap junctions and connexin-interacting proteins. Cardiovasc. Res. 2004, 62, $233-245$. [CrossRef] [PubMed]

225. Vendome, J.; Posy, S.; Jin, X.; Bahna, F.; Ahlsen, G.; Shapiro, L.; Honig, B. Molecular design principles underlying $\beta$-strand swapping in the adhesive dimerization of cadherins. Nat. Struct. Mol. Biol. 2011, 18, 693-700. [CrossRef] [PubMed]

226. Huber, A.H.; Stewart, D.B.; Laurents, D.V.; Nelson, W.J.; Weis, W.I. The cadherin cytoplasmic domain is unstructured in the absence of beta-catenin. A possible mechanism for regulating cadherin turnover. J. Biol. Chem. 2001, 276, 12301-12309. [CrossRef] [PubMed]

227. Pokutta, S.; Weis, W.I. Structure of the dimerization and beta-catenin-binding region of alpha-catenin. Mol. Cell 2000, 5, 533-543. [CrossRef]

228. Hirano, S.; Suzuki, S.T.; Redies, C. The cadherin superfamily in neural development: Diversity, function and interaction with other molecules. Front. Biosci. 2003, 8, d306-d355. [CrossRef] [PubMed]

229. Nollet, F.; Kools, P.; van Roy, F. Phylogenetic analysis of the cadherin superfamily allows identification of six major subfamilies besides several solitary members. J. Mol. Biol. 2000, 299, 551-572. [CrossRef] [PubMed]

230. Kim, S.A.; Tai, C.-Y.; Mok, L.-P.; Mosser, E.A.; Schuman, E.M. Calcium-dependent dynamics of cadherin interactions at cell-cell junctions. Proc. Natl. Acad. Sci. USA 2011, 108, 9857-9862. [CrossRef] [PubMed]

231. Takeichi, M.; Nakagawa, S. Cadherin-dependent cell-cell adhesion. In Current Protocols in Cell Biology; Wiley Online Library: Hoboken, NJ, USA, 2001.

232. Davis, M.A.; Ireton, R.C.; Reynolds, A.B. A core function for p120-catenin in cadherin turnover. J. Cell Biol. 2003, 163, 525-534. [CrossRef] [PubMed] 
233. Pokutta, S.; Drees, F.; Yamada, S.; Nelson, W.J.; Weis, W.I. Biochemical and structural analysis of alpha-catenin in cell-cell contacts. Biochem. Soc. Trans. 2008, 36, 141-147. [CrossRef] [PubMed]

234. Nagafuchi, A.; Ishihara, S.; Tsukita, S. The roles of catenins in the cadherin-mediated cell adhesion: Functional analysis of E-cadherin-alpha catenin fusion molecules. J. Cell Biol. 1994, 127, 235-245. [CrossRef] [PubMed]

235. Yonemura, S.; Wada, Y.; Watanabe, T.; Nagafuchi, A.; Shibata, M. Alpha-Catenin as a tension transducer that induces adherens junction development. Nat. Cell Biol. 2010, 12, 533-542. [CrossRef] [PubMed]

236. Buckley, C.D.; Tan, J.; Anderson, K.L.; Hanein, D.; Volkmann, N.; Weis, W.I.; Nelson, W.J.; Dunn, A.R. The minimal cadherin-catenin complex binds to actin filaments under force. Science 2014, 346, 1254211. [CrossRef] [PubMed]

237. Meng, W.; Mushika, Y.; Ichii, T.; Takeichi, M. Anchorage of microtubule minus ends to adherens junctions regulates epithelial cell-cell contacts. Cell 2008, 135, 948-959. [CrossRef] [PubMed]

238. Yang, J.; Dokurno, P.; Tonks, N.K.; Barford, D. Crystal structure of the M-fragment of alpha-catenin: Implications for modulation of cell adhesion. EMBO J. 2001, 20, 3645-3656. [CrossRef] [PubMed]

239. Desai, R.; Sarpal, R.; Ishiyama, N.; Pellikka, M.; Ikura, M.; Tepass, U. Monomeric $\alpha$-catenin links cadherin to the actin cytoskeleton. Nat. Cell Biol. 2013, 15, 261-273. [CrossRef] [PubMed]

240. Kobielak, A.; Fuchs, E. Alpha-catenin: At the junction of intercellular adhesion and actin dynamics. Nat. Rev. Mol. Cell Biol. 2004, 5, 614-625. [CrossRef] [PubMed]

241. Rangarajan, E.S.; Izard, T. Dimer asymmetry defines $\alpha$-catenin interactions. Nat. Struct. Mol. Biol. 2013, 20, 188-193. [CrossRef] [PubMed]

242. Escobar, D.J.; Desai, R.; Ishiyama, N.; Folmsbee, S.S.; Novak, M.N.; Flozak, A.S.; Daugherty, R.L.; Mo, R.; Nanavati, D.; Sarpal, R.; et al. $\alpha$-Catenin phosphorylation promotes intercellular adhesion through a dual-kinase mechanism. J. Cell Sci. 2015, 128, 1150-1165. [CrossRef] [PubMed]

243. Maiden, S.L.; Hardin, J. The secret life of alpha-catenin: Moonlighting in morphogenesis. J Cell Biol. 2011, 195, 543-552. [CrossRef] [PubMed]

244. Drees, F.; Pokutta, S.; Yamada, S.; Nelson, W.J.; Weis, W.I. Alpha-catenin is a molecular switch that binds E-cadherin-beta-catenin and regulates actin-filament assembly. Cell 2005, 123, 903-915. [CrossRef] [PubMed]

245. Giannini, A.L.; Vivanco, M.D.; Kypta, R.M. $\alpha$-catenin inhibits $\beta$-catenin signaling by preventing formation of a $\beta$-catenin T-cell factor DNA complex. J. Biol. Chem. 2000, 275, 21883-21888. [CrossRef] [PubMed]

246. Benjamin, J.M.; Kwiatkowski, A.V.; Yang, C.; Korobova, F.; Pokutta, S.; Svitkina, T.; Weis, W.I.; Nelson, W.J. $\alpha$ E-catenin regulates actin dynamics independently of cadherin-mediated cell-cell adhesion. J. Cell Biol. 2010, 189, 339-352. [CrossRef] [PubMed]

247. Scott, J.A.; Yap, A.S. Cinderella no longer: $\alpha$-catenin steps out of cadherin's shadow. J. Cell Sci. 2006, 119, 4599-4605. [CrossRef] [PubMed]

248. Weis, W.I.; Nelson, W.J. Re-solving the cadherin-catenin-actin conundrum. J. Biol. Chem. 2006, 281, 35593-35597. [CrossRef] [PubMed]

249. Izard, T.; Evans, G.; Borgon, R.A.; Rush, C.L.; Bricogne, G.; Bois, P.R.J. Vinculin activation by talin through helical bundle conversion. Nature 2004, 427, 171-175. [CrossRef] [PubMed]

250. Borghi, N.; Sorokina, M.; Shcherbakova, O.G.; Weis, W.I.; Pruitt, B.L.; Nelson, W.J.; Dunn, A.R. E-cadherin is under constitutive actomyosin-generated tension that is increased at cell-cell contacts upon externally applied stretch. Proc. Natl. Acad. Sci. USA 2012, 109, 12568-12573. [CrossRef] [PubMed]

251. Tabdili, H.; Barry, A.K.; Langer, M.D.; Chien, Y.-H.; Shi, Q.; Lee, K.J.; Lu, S.; Leckband, D.E. Cadherin point mutations alter cell sorting and modulate GTPase signaling. J. Cell Sci. 2012, 125, 3299-3309. [CrossRef] [PubMed]

252. Liu, Z.; Tan, J.L.; Cohen, D.M.; Yang, M.T.; Sniadecki, N.J.; Ruiz, S.A.; Nelson, C.M.; Chen, C.S. Mechanical tugging force regulates the size of cell-cell junctions. Proc. Natl. Acad. Sci. USA 2010, 107, 9944-9949. [CrossRef] [PubMed]

253. Nelson, C.M.; Pirone, D.M.; Tan, J.L.; Chen, C.S. Vascular endothelial-cadherin regulates cytoskeletal tension, cell spreading, and focal adhesions by stimulating RhoA. Mol. Biol. Cell 2004, 15, 2943-2953. [CrossRef] [PubMed]

254. Leckband, D.E.; le Duc, Q.; Wang, N.; de Rooij, J. Mechanotransduction at cadherin-mediated adhesions. Curr. Opin. Cell Biol. 2011, 23, 523-530. [CrossRef] [PubMed]

255. Muhamed, I.; Wu, J.; Sehgal, P.; Kong, X.; Tajik, A.; Wang, N.; Leckband, D.E. E-Cadherin-mediated force transduction signals regulate global cell mechanics. J. Cell Sci. 2016, 129, 1843-1854. [CrossRef] [PubMed] 
256. Perez, T.D.; Tamada, M.; Sheetz, M.P.; Nelson, W.J. Immediate-early signaling induced by E-cadherin engagement and adhesion. J. Biol. Chem. 2008, 283, 5014-5022. [CrossRef] [PubMed]

257. Sahai, E.; Marshall, C.J. ROCK and Dia have opposing effects on adherens junctions downstream of Rho. Nat. Cell Biol. 2002, 4, 408-415. [CrossRef] [PubMed]

258. Reynolds, A.B.; Roczniak-Ferguson, A. Emerging roles for p120-catenin in cell adhesion and cancer. Oncogene 2004, 23, 7947-7956. [CrossRef] [PubMed]

259. Balsamo, J. The Nonreceptor Protein Tyrosine Phosphatase PTP1B Binds to the Cytoplasmic Domain of N-Cadherin and Regulates the Cadherin-Actin Linkage. J. Cell Biol. 1998, 143, 523-532. [CrossRef] [PubMed]

260. Brady-Kalnay, S.M.; Rimm, D.L.; Tonks, N.K. Receptor protein tyrosine phosphatase PTPmu associates with cadherins and catenins in vivo. J. Cell Biol. 1995, 130, 977-986. [CrossRef] [PubMed]

261. McLachlan, R.W.; Yap, A.S. Protein tyrosine phosphatase activity is necessary for E-cadherin-activated Src signaling. Cytoskeleton 2011, 68, 32-43. [CrossRef] [PubMed]

262. Hsu, K.-S.; Huang, C.-C.; Liang, Y.-C.; Wu, H.-M.; Chen, Y.-L.; Lo, S.-W.; Ho, W.C. Alterations in the balance of protein kinase and phosphatase activities and age-related impairments of synaptic transmission and long-term potentiation. Hippocampus 2002, 12, 787-802. [CrossRef] [PubMed]

263. Breitkreutz, A.; Choi, H.; Sharom, J.R.; Boucher, L.; Neduva, V.; Larsen, B.; Lin, Z.Y.; Breitkreutz, B.J.; Stark, C.; Liu, G.; et al. A global protein kinase and phosphatase interaction network in yeast. Science 2010, 328, 1043-1046. [CrossRef] [PubMed]

264. Resink, T.J.; Philippova, M.; Joshi, M.B.; Kyriakakis, E.; Erne, P. Cadherins and cardiovascular disease. Swiss Med. Wkly. 2009, 139, 122-134. [PubMed]

265. Schulte, D.; Küppers, V.; Dartsch, N.; Broermann, A.; Li, H.; Zarbock, A.; Kamenyeva, O.; Kiefer, F.; Khandoga, A.; Massberg, S.; et al. Stabilizing the VE-cadherin-catenin complex blocks leukocyte extravasation and vascular permeability. EMBO J. 2011, 30, 4157-4170. [CrossRef] [PubMed]

266. Vestweber, D. VE-cadherin: The major endothelial adhesion molecule controlling cellular junctions and blood vessel formation. Arterioscler. Thromb. Vasc. Biol. 2008, 28, 223-232. [CrossRef] [PubMed]

267. Ouyang, M.; Lu, S.; Kim, T.; Chen, C.-E.; Seong, J.; Leckband, D.E.; Wang, F.; Reynolds, A.B.; Schwartz, M.A.; Wang, Y. N-cadherin regulates spatially polarized signals through distinct $\mathrm{p} 120 \mathrm{ctn}$ and $\beta$-catenin-dependent signalling pathways. Nat. Commun. 2013, 4, 1589. [CrossRef] [PubMed]

268. Alenghat, F.J.; Nauli, S.M.; Kolb, R.; Zhou, J.; Ingber, D.E. Global cytoskeletal control of mechanotransduction in kidney epithelial cells. Exp. Cell Res. 2004, 301, 23-30. [CrossRef] [PubMed]

269. Collins, C.; Tzima, E. RhoA goes GLOBAL. Small GTPases. 2013, 4, 123-126. [CrossRef] [PubMed]

270. Ingber, D.E.; Tensegrity, I. Cell structure and hierarchical systems biology. J. Cell Sci. 2003, 116, 1157-1173. [CrossRef] [PubMed]

271. Hu, S.; Chen, J.; Fabry, B.; Numaguchi, Y.; Gouldstone, A.; Ingber, D.E.; Fredberg, J.J.; Butler, J.P.; Wang, N. Intracellular stress tomography reveals stress focusing and structural anisotropy in cytoskeleton of living cells. Am. J. Physiol. Cell Physiol. 2003, 285, C1082-C1090. [CrossRef] [PubMed]

272. Vogel, V.; Sheetz, M. Local force and geometry sensing regulate cell functions. Nat. Rev. Mol. Cell Biol. 2006, 7, 265-275. [CrossRef] [PubMed]

273. Orr, A.W.; Helmke, B.P.; Blackman, B.R.; Schwartz, M.A. Mechanisms of Mechanotransduction. Dev. Cell 2006, 10, 11-20. [CrossRef] [PubMed]

274. Ladoux, B.; Nicolas, A. Physically based principles of cell adhesion mechanosensitivity in tissues. Rep. Prog. Phys. 2012, 75, 116601. [CrossRef] [PubMed]

275. Janmey, P.A.; McCulloch, C.A. Cell mechanics: Integrating cell responses to mechanical stimuli. Annu. Rev. Biomed. Eng. 2007, 9, 1-34. [CrossRef] [PubMed]

276. Beningo, K.A.; Lo, C.-M.; Wang, Y.-L. Flexible polyacrylamide substrata for the analysis of mechanical interactions at cell-substratum adhesions. Methods Cell Biol. 2002, 69, 325-339. [PubMed] 
277. Deng, L.; Fairbank, N.J.; Fabry, B.; Smith, P.G.; Maksym, G.N. Localized mechanical stress induces time-dependent actin cytoskeletal remodeling and stiffening in cultured airway smooth muscle cells. Am. J. Physiol. Cell Physiol. 2004, 287, C440-C448. [CrossRef] [PubMed]

278. Geiger, B.; Yamada, K.M. Molecular architecture and function of matrix adhesions. Cold Spring Harb. Perspect. Biol. 2011, 3, a005033. [CrossRef] [PubMed]

(C) 2017 by the authors; licensee MDPI, Basel, Switzerland. This article is an open access article distributed under the terms and conditions of the Creative Commons Attribution (CC BY) license (http:/ / creativecommons.org/licenses/by/4.0/). 